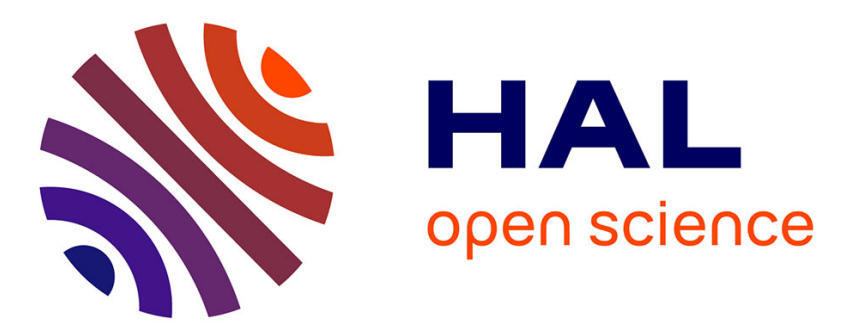

\title{
Primary vitreoretinal lymphoma: a diagnostic and management challenge
}

Carole Soussain, Denis Malaise, Nathalie Cassoux

\section{To cite this version:}

Carole Soussain, Denis Malaise, Nathalie Cassoux. Primary vitreoretinal lymphoma: a diagnostic and management challenge. Blood, 2021, 138 (17), pp.1519-1534. 10.1182/blood.2020008235 . hal03559353

\section{HAL Id: hal-03559353 https://hal.science/hal-03559353}

Submitted on 20 Feb 2022

HAL is a multi-disciplinary open access archive for the deposit and dissemination of scientific research documents, whether they are published or not. The documents may come from teaching and research institutions in France or abroad, or from public or private research centers.
L'archive ouverte pluridisciplinaire HAL, est destinée au dépôt et à la diffusion de documents scientifiques de niveau recherche, publiés ou non, émanant des établissements d'enseignement et de recherche français ou étrangers, des laboratoires publics ou privés. 


\section{Primary vitreoretinal lymphoma: A diagnostic and management challenge}

\section{- Review Article -}

Carole Soussain, MD, PhD, Institut Curie, Site de Saint-Cloud, Hematology Department, INSERM U932 Institut Curie, PSL Research University, Paris, France, and French Network for Oculo-cerebral Lymphomas (LOC network)

Denis Malaise, MD, Institut Curie, Ophthalmology Department, Paris France Institut Curie, PSL University, Inserm U1288, Laboratoire d'Imagerie Translationnelle en Oncologie, 91400 Orsay, France

Nathalie Cassoux, MD, PhD, Institut Curie, Ophthalmology Department, Paris France, Université de Paris, UMR 144 CNRS, and French Network for Oculo-cerebral Lymphomas (LOC network)

Corresponding author: Carole Soussain, Institut Curie, Hématologie, 35 rue Dailly 92210 Saint-Cloud, France. Phone: (+ 331) 4711 1536. Email: carole.soussain@curie.fr

Conflicts of interest: none

Authors' contributions

Conception and design: CS

Administrative support: Not applicable

Provision of study materials or patients: CS, DM, and NC

Collection and assembly of data: CS, DM, and NC

Data analysis and interpretation: CS, DM, and NC

Manuscript writing: CS, DM, and NC

Final approval of manuscript: CS, DM, and NC

CS, DM, and NC declare no conflicts of interest

The authors received no funding for this review.

Acknowledgment: We thank Magali Le Garff-Tavernier, Pharm MD, PhD, and Frederic Davi, $M D, P h D$, for the fruitful discussions on the biology of PVRL. 


\section{Abstract}

Primary vitreoretinal lymphoma (PVRL) is a rare form of primary central nervous system lymphoma (PCNSL) arising in the intraocular compartment without brain involvement. Despite its apparent indolent clinical course, PVRL can cause permanent vision loss and CNS relapse, the major cause of death in PVRL patients. The pathophysiology of PVRL is unknown. As in PCNSL, the transformation of the tumor cells likely originates outside the CNS, before the cells migrate to the eye and proliferate within an immune-permissive microenvironment. PVRL exhibits a biased immunoglobulin repertoire, suggesting underlying antigen selection. The diagnosis remains challenging, requiring close coordination between ophthalmologists and cytologists. Because of their rarity and fragility in the vitreous, lymphoma cells cannot always be identified. Interleukin levels, molecular biology and imaging are used in combination with clinical ophthalmological examination to support the diagnosis of PVRL.

Multi-institutional prospective studies are urgently needed to validate the equivocal conclusions regarding treatments drawn from heterogeneous retrospective or small cohort studies. Intravitreal injections of methotrexate or rituximab or local radiotherapy are effective at clearing tumor cells within the eyes but do not prevent CNS relapse. Systemic treatment based on high-dose methotrexate chemotherapy, with or without local treatment, might reduce this risk. At relapse, intensive consolidation chemotherapy followed by stem cell transplantation can be considered. Single-agent ibrutinib, lenalidomide and temozolomide treatments are effective in patients with relapsed PVRL and should be tested as first-line treatments. Therapeutic response assessment based on a clinical examination is improved by measuring cytokine levels but still needs to be refined. 


\section{INTRODUCTION}

Primary vitreoretinal lymphomas (PVRLs) arise in the intraocular compartment without brain involvement, thus constituting a rare subgroup of primary central nervous system lymphoma $(\mathrm{PCNSL})^{1}$. Due to the clinical similarities to uveitis and initial response to steroid therapy, the PVRL diagnosis may be delayed. The initial indolent clinical course must not minimize the severity of this disease, which can result in permanent vision loss or CNS relapse with a poor prognosis. Therapeutic options range from local ocular treatment to systemic therapy based on high-dose methotrexate (HD-MTX) and even intensive chemotherapy with autologous stem cell transplantation (IC+ASCT). The diagnostic procedure is improved by analyses of biomarkers and molecular biological parameters. Efforts are needed to better assess the therapeutic response.

This review aims to summarize the most important studies in the field of PVRL, including their pitfalls and limitations, to assist with decision-making in clinical practice and to better identify the next challenges to address in this disease.

\section{DEFINITION AND EPIDEMIOLOGY}

PVRL is a rare high-grade extranodal non-Hodgkin lymphoma affecting the vitreous, retina or, exceptionally, the optic nerve in the absence of brain parenchyma infiltration.

PVRL must be distinguished from secondary vitreoretinal or choroidal invasion by a systemic lymphoma and from primary uveal lymphomas, which arise in the choroid, iris or ciliary body and are mainly MALT (mucosa-associated lymphoid tissue) lymphomas (figure 1$)^{2}$. The vitreoretinal involvement present at the diagnosis of a PCNSL, which occurs in $15 \%$ of patients with PCNSL ${ }^{3}$, falls outside the definition of PVRL.

The majority of PVRLs are high-grade diffuse large B-cell lymphomas (DLBCLs) ${ }^{4}$. Analogous to PCNSL, one can suggest that PVRL also belongs to the activated-B cell type $(A B C)^{5}$, more specifically to the subgroup of $A B C-D L B C L$, with frequent mutations in CD79 and MYD88 $265 \mathrm{P}$ and a less favorable outcome than other $A B C$ subgroups $^{6,7}$. Exceptional unclassifiable B-cell lymphoma, follicular lymphoma and T-cell lymphoma are encountered.

True epidemiological data are lacking. The PVRL incidence is estimated to be 50 cases/year in the US ${ }^{4}$. PVRL represents approximately $5 \%$ of the patients registered in the French 
database for oculo-cerebral lymphomas and accounts for 10 new cases/year ${ }^{3,8}$. PVRL usually occurs in immunocompetent adults during the fifth decade with a slight female predominance but no racial predilection ${ }^{4,9}$. Some cases have been described in patients with immunosuppression, usually associated with Epstein-Barr virus ${ }^{10}$. PVRL is mainly bilateral although asymmetric presentations are encountered.

\section{PATHOPHYSIOLOGY OF PVRL AND CNS RELAPSE}

PVRL pathophysiology remains to be deciphered. The lymphoma cell origin is unknown, but similarly to PCNSL, the transformation of the tumor cells likely originates outside the CNS, before the cells migrate to the eye and proliferate. The microenvironments of the CNS and the eyes share similar characteristics. The retina is isolated from the vascular and perivascular compartment by two blood-retinal barriers (BRBs), composed of cells linked by tight junctions at the level of the intraretinal capillary endothelial cells (inner BRB) and the retinal pigmented epithelium (RPE) (outer BRB), which substantially restrict paracellular diffusion of molecules into the retina from the vascular and perivascular compartments, respectively ${ }^{11}$. The ocular microenvironment shows low expression of major histocompatibility complex class molecules and is enriched in immunosuppressive molecules, such as transforming growth factor-beta, macrophage migration inhibitory factor and Fas ligands, which suppress the activation of Th1 cells and the inflammatory activity of macrophages and prevent natural killer cell activation. The secretion of interleukin-10 (IL10), an immunosuppressive cytokine, by lymphoma cells may increase immune tolerance and allow tumor cells to escape the immune system ${ }^{12,13}$. Data on ocular immune reactions to tumor cells are scarce. Impaired Th1 cytokine production by tumor-infiltrating lymphocytes has been documented in PVRL animal models ${ }^{13}$.

According to a recent study ${ }^{14}$, PVRLs displayed very high levels of immunoglobulin (IG) gene mutations, especially in the IGHV4-34 sequences, and in a significantly higher proportion than in PCNSL. This biased IG repertoire suggests that antigen selection plays a major role in PVRL development and highlights a potential role for inhibitors of the B-cell receptor (BCR) signaling pathway in blocking the activity of the NF-KB pathway, which is activated in ABCDLBCL ${ }^{15}$. The galectin-3 protein, which is recognized by antibodies using the IGHV4-34 gene 
and is expressed in cells from both the brain microenvironment and RPE, is a candidate antigen $^{14,16}$. Further studies are needed to identify the antigen responsible for PVRL.

The pathophysiology of CNS relapse from PVRL is poorly documented. Whether CNS relapse results from subclinical brain disease involvement that is not detectable with routine magnetic resonance imaging (MRI) at diagnosis or from dissemination from the eye through the retina and optic nerve is still a matter of debate. Experiments using murine models ${ }^{17,18}$ support the hypothesis of dissemination through the RPE into the choroid, thus highlighting the importance of achieving complete remission in the eye. The detection of IL-10 in the cerebro-spinal fluid (CSF) of patients with PVRL, without CSF or brain involvement of lymphoma ${ }^{19}$, might suggest a subclinical brain involvement of the disease ${ }^{19}$.

\section{DIAGNOSIS}

Distinguishing PVRL from posterior uveitis is still a challenge for ophthalmologists. PVRL is part of the well-named masquerade syndrome: an insidious onset, initial response to steroids and delayed diagnosis due in part to the common prolonged and indiscriminate use of steroids are common ${ }^{4}$. The median time from first symptoms to diagnosis ranges from 6 to 40 months ${ }^{9,20,21}$ compared to 35 days for PCNSL ${ }^{22}$. Patients may complain of floaters or blurred vision ${ }^{4}$. A slit-lamp examination reveals a quiet anterior chamber with no protein flare and some cellular gray diffuse keratic precipitates. Lymphoma cell clumps are noticeable in the anterior vitreous or along the vitreous fibrils. Lymphoma cells may also infiltrate the retina (multifocal cream-colored retinal spots on funduscopic imaging) or grow along the Bruch membrane under the RPE. Multimodal retinal imaging reveals the typical but nonpathognomonic leopard skin pattern, while subretinal cell deposits are highlighted with noninvasive optical coherence tomography (OCT) (figure 2). Clinical findings and paraclinical signs of PVRL and uveitis are summarized in table 1.

Although an ophthalmic examination and ocular imaging might raise clinical suspicion ${ }^{23}$, the gold standard for PVRL diagnosis is still the cytological identification of lymphomatous cells in the eye (figure 3). A diagnostic vitrectomy is usually performed. Less frequently, a retinal biopsy is necessary. A cytological examination, immunocytochemistry, flow cytometry, measurement of cytokine levels and molecular examinations of these samples should be combined to improve the sensitivity and specificity of the PVRL diagnosis ${ }^{10}$. The diagnosis 
could remain challenging owing to a limited sample volume, low cellularity of vitreous fluid samples and the extreme fragility of lymphoma cells in the vitreous. The procedures for vitreous sampling and analysis have been described previously ${ }^{24-27}$ (table 2). We must emphasize that for a successful diagnostic procedure the discontinuation of steroids several weeks before vitrectomy, good communication and collaboration between the ophthalmologist and the cytologist/pathologist trained in handling vitreous samples, and an immediate analysis of both pure and diluted vitreous samples preferentially without a fixative are critical.

Cytology provides morphological evidence of PVRL. Owing to the difficulties of sampling, the sensitivity of cytology alone in diagnosing PVRL is low $(45-60 \%)^{28}$. Immunohistochemistry or flow cytometry of pan B-cell markers can show a CD20+ population of B-cells with monotypic light chain expression ${ }^{29,30}$. Monoclonality can be identified by polymerase chain reaction (PCR) to detect immunoglobulin heavy-chain or Kappa light-chain gene rearrangement ${ }^{31-33}$. Results of flow cytometry and PCR analyses must be interpreted with caution in samples with low cellularity.

IL-10 measurements in pure vitreous or aqueous samples are a significant diagnostic aid when PVRL is clinically suspected. High IL-10 levels in vitreous or anterior chamber favor a diagnosis of PVRL, while high IL-6 levels are more specific to inflammatory or infectious diseases. The IL-10/IL-6 ratio is thus very helpful in determining the PVRL diagnosis ${ }^{34-36}$ while avoiding errors related to sample dilution. Caution remains for pure retinal localization, which may not be accompanied by an increase in IL-10 in intraocular fluids. Cassoux et al. ${ }^{12}$ defined a specific cutoffs of $50 \mathrm{pg} / \mathrm{mL} \mathrm{IL-10} \mathrm{in} \mathrm{the} \mathrm{aqueous} \mathrm{humor} \mathrm{(sensitivity} \mathrm{of} \mathrm{89 \% ;}$ specificity of $93 \%$ ) and $400 \mathrm{pg} / \mathrm{mL}$ in the vitreous (sensitivity of $80 \%$; specificity of $99 \%$ ) (figure 4). More recently, an Interleukin Score for intraOcular Lymphoma Diagnosis (ISOLD) was proposed as a probability score for the diagnosis of PVRL (figure 4$)^{37}$, which combines the IL-10 and IL-6 levels. Assessments of interleukin levels are currently routine procedures for the screening and follow-up of PVRL in many referral centers, as an anterior chamber tap is a rapid and minimally invasive procedure ${ }^{38}$.

MYD88 and CD79B gene mutations are frequently reported in PCNSL ${ }^{7}$. The most common mutation, MYD88 ${ }^{\mathrm{L265P}}$, increases NF-KB activity, which promotes cell survival ${ }^{39}$. The MYD88 ${ }^{\text {L265P }}$ mutation was observed in the vitreous in up to $88 \%$ of a series of 25 patients with PVRL ${ }^{40}$. Adding the MYD88 gene mutation test might improve the diagnostic yield of 
vitreous fluid ${ }^{41}$. Concomitant MYD88 mutations were detected in paired aqueous and vitreous samples from small series of patients ${ }^{42,43}$.

$C D 79 B$, which encodes the $B C R$, was mutated in $35 \%$ of a series of 17 patients with $P V R L^{44}$. Yonese et al. ${ }^{44}$ suggested an association between the $C D 79 B$ mutation and a poorer prognosis due to earlier CNS involvement.

Recent epigenetic studies identified microRNAs such as miR-6513-3p and miR-1236-3p in the vitreous and serum that might serve as candidate PVRL biomarkers ${ }^{45,46}$. Whole-exome sequencing to determine the PVRL mutation profile has recently been conducted but small targeted gene panel tests remain to be developed ${ }^{47}$.

In summary, a definite PVRL diagnosis relies on the cytological identification of malignant lymphoid cells with monotypic and/or clonal characteristics. This diagnosis may be challenging when cytological evidence of PVRL is lacking because of a low-cellularity or poorquality sample. In these cases, the PVRL diagnosis will be highly probable based on evidence from multiple tests combining an ophthalmological clinical examination, imaging (such as angiography or OCT) and measurements of IL-10/IL-6 levels for ISOLD scoring.

Cerebral MRI, CSF examination including cytology and ideally flow-cytometry for lymphoid markers, CT or PET/CT of chest/abdomen and pelvis, and bone marrow biopsy, are necessary in the initial disease assessment to rule out brain and extraCNS lymphoma involvement.

\section{THERAPEUTIC ISSUES}

Therapeutic challenges for PVRL are dual. Local and CNS relapses are frequent. Fifty-six to 90\% of patients with PVRL ultimately develop CNS dissemination within 30 months ${ }^{4,9,48}$. Median progression-free survival (PFS) ranges from 18 to 29 months ${ }^{8,9}$. Overall survival (OS), ranging from 58 to 75 months ${ }^{8,9}$, is however longer than the estimated survival of patients with PCNSL ${ }^{22}$. Therapy aims to treat the intraocular and retinal disease to restore the patient's vision and to decrease the incidence of CNS relapses, which represent the main cause of death ${ }^{4,48,49}$.

Different treatment strategies are available ${ }^{9,50-57}$ : local treatment, such as intravitreal (IVT) injection of chemotherapy or ocular radiotherapy (ORT); systemic treatment; or a 
combination of both. Debate persists regarding which strategy to adopt as the first-line treatment. The large number of published studies reflects the efforts of medical teams to improve the prognosis of patients with PVRL. However, many pitfalls hinder their interpretation. The largest retrospective studies involved patients who received multiple treatments, resulting in small subgroups receiving similar treatments. The few prospective studies available were conducted in a very limited number of patients. Interestingly, the median survival appears longer in patients treated at the time of the PVRL diagnosis than in patients treated at the time of CNS relapse $\mathrm{e}^{58}$.

How patients are monitored for the early detection of an ocular or CNS relapse is usually not specified in the published series. Differences in monitoring procedures may account for part of the observed differences in PFS.

\section{First-line treatments}

Local treatments

The goal of local treatment is to induce intraocular complete remission (CR) and improve vision without systemic toxicity. Studies have not proved whether the achievement of a local CR reduces the risk of CNS relapse.

The IVT route for chemotherapy is an interesting procedure to rapidly reach intraocular cytotoxic drug concentration. Data on the ocular bioavailability of IVT chemotherapy are scarce. De Smet et al. ${ }^{59}$ showed that a single IVT injection of $400 \mu \mathrm{g}$ of methotrexate remained effective for more than 5 days (table 2). Kim et al. ${ }^{60}$ determined that the half-life of rituximab in the rabbit vitreous (IVT injection of $1 \mathrm{mg} / 0.1 \mathrm{~mL}$ ) is 4.7 days.

IVT injections are a safe procedure performed under topical anesthesia ${ }^{61}$. Methotrexate is the main drug used for IVT injection at a dose of $0.4 \mathrm{mg} / 0.1 \mathrm{~mL}$. Various IVT administration schedules have been published (supplemental data) ${ }^{62-65}$. The induction phase consists of twice-weekly IVT for 4 weeks. The treatment is then followed by a predetermined number of IVT injections (for a total of 25 IVT injections over one year) or driven by the clinical response or the IL-10 level in the aqueous humor ${ }^{51,65,66}$ to decrease the number of IVT injections.

IVT rituximab injections at a dose of $1 \mathrm{mg} / 0.1 \mathrm{~mL}$, alone or combined with IVT injections of methotrexate, are an interesting alternative that would require fewer injections to control PVRL. Protocols vary between authors ${ }^{66-68}$. Some authors also reported IVT injections of melphalan 69,70 . 
The main IVT methotrexate-related side effects are transient intraocular hypertonia, epithelial keratopathy ${ }^{63,64}$ and, in some cases, drug resistance ${ }^{71}$. Reversible uveitis may occur after IVT rituximab ${ }^{68}$. These side effects are reduced by performing an anterior chamber tap before the IVT injection to reduce intraocular pressure and drug reflux and abundant washing of the cornea with saline. The obtained aqueous sample is then used to monitor the IL-10 level. Intraocular hemorrhage, retinal detachment or endophthalmitis are rare visionthreatening side effects caused by the procedure of IVT injections $(0.06,0.01$ and $0.05 \%$ of injections, respectively) $)^{72}$.

IVT chemotherapy has been used as first-line treatment, while some authors use IVT chemotherapy only for ocular relapses or when systemic chemotherapy is contraindicated ${ }^{4,66,73}$. The efficacy of IVT chemotherapy as the sole first-line treatment for PVRL cannot be properly assessed because of the heterogeneity encountered in retrospective studies in terms of disease characteristics (initial PVRL or relapse, vitreo-retinal involvement associated with PCNSL) and the frequent association of systemic treatments.

External beam ORT (30-40 Gy) is an alternative local treatment although it is rarely offered as the only first-line treatment ${ }^{4}$. It is effective for local control of the disease and may be preferable in patients with bilateral disease ${ }^{4}$, but fails to prevent the CNS relapse. The risk of

cataract and radiation retinopathy decreases with lower doses (<30 Gy) of ORT ${ }^{9,58,66,74-76}$.

Therapeutic vitrectomy can be considered a palliative treatment to improve vision ${ }^{77}$.

\section{Systemic and combined (local + systemic) treatments}

Systemic treatments are empirical and mainly rely on PCNSL-like treatments with HD-MTX, based on the anatomical and functional similarities between the blood-brain barrier and the $\mathrm{BRB}^{11}$. Knowledge of the pharmacokinetic of drugs administered systemically in ocular tissues and fluid is scarce; it has been explored in a few studies of a small number of patients (table 3). After IV HD-MTX and aracytine administration, these drugs were found in the aqueous humor and to a lesser extent in the vitreous shortly after the injection ${ }^{78-80}$. Ifosfamide and trofosfamide were detectable in the aqueous humor after IV and oral administration respectively ${ }^{81}$, but the data in the vitreous are lacking for these drugs. 
The benefit of combining a first-line treatment with systemic HD-MTX chemotherapy and local treatment to decrease the risk of CNS relapse is controversial based on the results of heterogeneous retrospective studies ${ }^{9,50-57,82}$ (table 4) that aimed to compare the outcome of patients who received only local treatment with the outcomes of patients who received systemic treatment or a combination of both. The retrospective study by Hashida ${ }^{55}$, in which the treatments were more homogeneous, showed significantly delayed CNS relapses in patients who received a combination of local and systemic HD-MTX treatment. Due to the aforementioned biases of the published therapeutic studies in patients with PVRL, the failure of retrospective studies to prove the superiority of the combined therapeutic approaches should not discourage clinicians from testing treatments with the objective of decreasing CNS relapse. Kaburaki et al. ${ }^{57}$ reported encouraging results from a small prospective series of 11 patients treated with a conventional PCNSL-like treatment consisting of systemic IV RMPV (rituximab, HD-MTX, procarbazine, vincristine) + reduced-dose whole-brain radiotherapy (23.4 Gy) + IV HD-AraC combined with IVT-MTX. With a median follow-up of 40 months, the estimated 4-year cumulative incidence of CNS progression was only $10 \%$. The combination of bilateral ORT (30-40 Gy) with systemic HD-MTX produced encouraging survival results in a cohort of 11 patients, but resulted in radiation retinopathy in 9 patients (with optic atrophy $(n=2)$ or cataract $(n=2))$ and bilateral optic nerve atrophy in one patient ${ }^{82}$.

\section{Treatments for relapsed or refractory PVRL}

At relapse, IVT chemotherapy and ORT can be provided as a single treatment with the same objectives as discussed in first-line treatment or to rapidly improve vision in combination with systemic treatment.

\section{Intensive chemotherapy followed by autologous stem cell transplantation (IC+ASCT)}

$I C+A S C T$ has been evaluated in patients with refractory or relapsed $(R / R)$ PVRL to circumvent the blood-retina barrier ${ }^{83-85}$, mainly with an IC regimen consisting of HD thiotepa-busulfancyclophosphamide, because this combination of drugs proved feasible and effective in patients with poor-prognosis systemic lymphomas, including patients with CNS disease involvement ${ }^{86}$, and because thiotepa and busulfan have good CNS bioavailability ${ }^{87}$. IC + ASCT proved feasible in patients with R/R PVRL (table 5). A pilot study reported encouraging results for patients with refractory PVRL after induction chemotherapy based on HD-MTX 
and HD-AraC ${ }^{83}$ : the 5 patients who received IC+ASCT achieved a CR and no CNS relapse was observed after ASCT with a median follow-up of 17 months. Patients with R/R PVRL were included in subsequent retrospective ${ }^{85}$ and prospective $^{84}$ studies for R/R PCNSL and PVRL with the same IC+ASCT regimen. These studies confirmed the efficacy of this therapeutic procedure in patients with R/R PCNSL and PVRL, with no significant different outcomes between patients with PVRL and PCNSL. Other retrospective studies ${ }^{52}$ also suggested a beneficial effect of IC+ASCT on PVRL. Although these statements are based on a small series of patients with PVRL, due to the rarity of this disease, and in the absence of any comparative studies, IC+ASCT can still be considered a treatment option for relapsed PVRL in younger patients with no severe comorbidities.

\section{Single agents and targeted therapies (table 5)}

Single-agent temozolomide produced encouraging results in a retrospective study involving 21 patients (relapse, $n=19$; first-line, $n=2$ ) 88 . The overall response rate (ORR) was $81 \%$, with $71 \%$ achieving a CR. The toxicity profile was good. With a median follow-up of 42 months, the median PFS was 12 months and 5 CNS relapses occurred.

Two targeted therapies, lenalidomide as a single agent or combined with rituximab, and ibrutinib, showed clinical activity in the ocular compartment in phase I and prospective "proof-of-concept" phase II studies ${ }^{89-92}$ (table 5). These therapies were tested because of their known efficacy against systemic DLBCL, with preferential antilymphoma activity against the ABC-DLBCL subtype 5,14,93,94.

In the REVRI study ${ }^{89}$, the induction treatment consisted of eight 28-day cycles of R2 (rituximab 375/m² IV D1; lenalidomide 20 mg/day, D1-21 for cycle 1; and 25 mg/day, D1-21 for the subsequent cycles). Fifty patients were recruited in the study, including seventeen patients with intraocular disease involvement (11 patients with R/R PVRL and 6 patients with disease involvement of the brain and eyes). In this patient subgroup, the CR rate was 35\%. The median PFS of patients with PVRL was 9.2 months. The median OS of patients with PVRL was not reached and was significantly longer than that of patients with PCNSL $(p=0.03)$. Although the precise roles of rituximab and lenalidomide in determining the therapeutic 
outcomes in this population cannot be defined, this study documented the clinical activity of the combination of rituximab and lenalidomide in the ocular compartment.

The prospective multicenter phase $\|$ ILOC study ${ }^{90}$ evaluated the activity of ibrutinib as a single agent ( $560 \mathrm{mg} /$ day every day) in patients with R/R PCNSL and PVRL. Fourteen patients with R/R PVRL were included. After 2 months of treatment, an ORR was observed in $86 \%$ of patients with intraocular disease involvement, including CR in 50\%. The median PFS of patients with PVRL was 23 months. After a median follow-up of 26 months, one CNS relapse was observed.

\section{ASSESSMENT OF THE THERAPEUTIC RESPONSE AND FOLLOW-UP}

According to IPCG95, the definition of an ocular CR requires "no evidence of active ocular lymphoma as defined by the absence of cells in the vitreous and resolution of any previously documented retinal or optic nerve infiltrates". In practice, the response to treatment is assessed by a clinical ophthalmological evaluation ${ }^{96}$, which aims to assess the reduction in vitreous and retinal invasion by tumor cells. However, this evaluation is subjective. The ophthalmological definitions of $C R$, partial response and relapse are difficult to determine since a measurable mass is not present. Tumor vitreous haze and retinal infiltration are observer-dependent measures. True CR is difficult to ascertain, as many patients present minimal residual disease, which is difficult to distinguish from an active infiltrate ${ }^{97}$. Assessment of the PVRL response is a major challenge. Indeed, PVRL is currently the only aggressive lymphoma for which the assessment of a response to treatment is based on a clinical evaluation, which differs substantially from the recommendation for systemic lymphoma ${ }^{98}$.

Ancillary ophthalmological examinations, such as OCT, could provide interesting noninvasive, reproducible and comparative information about the evolution of retinal lesions (figure 5), as evidenced by a retrospective case analysis ${ }^{96}$. However, multimodal imaging including retinal photography, angiography and OCT enables an assessment of the posterior pole of the eye and the retinal lesion, but not the vitreous infiltration.

IL-10 is a promising biomarker. Exploratory studies have shown that the decrease in IL-10 levels in the aqueous humor is a minimally invasive indicator of the treatment response, while an increase might suggest recurrence ${ }^{66}$. This biomarker might facilitate early relapse 
detection ${ }^{12}$. Prospective studies evaluating specific correlations between IL-10 levels and clinical CR, PFS or OS are lacking.

After CR is achieved, rigorous follow-up ${ }^{97}$ is essential to assess CR persistence and to verify the absence of tumoral invasion in the contralateral eye, which requires prompt treatment. Brain MRI should also be performed regularly to exclude secondary asymptomatic CNS involvement ${ }^{97}$.

\section{PERSPECTIVES AND CONCLUSIONS}

In clinical practice, several therapeutic options are available, from local treatments to systemic chemotherapies and IC+ASCT, with practices that differ between ophthalmologists and oncologists/hematologists. IVT chemotherapy, mainly MTX and rituximab, or ORT can rapidly decrease vitreous disease involvement and improve vision but will not prevent the risk of CNS relapse. Local treatments still represent convenient symptomatic therapeutic options in patients with persistent PVRL who are unable to receive systemic treatment either because of their characteristics and comorbidities or the failure of systemic treatments. Although the lack of multi-institutional prospective studies prevents unequivocal conclusions on the superiority of one specific therapeutic approach, our own preference is to initially provide a PCNSL-like treatment with additional local ophthalmic treatment to younger patients with the objective of achieving a local CR and preventing CNS relapse. Nonetheless, the best combined treatment has not yet been defined. Encouraging results have been observed with single-agent oral temozolomide, ibrutinib and lenalidomide in patients with relapsed or refractory PVRL, supporting the need to assess these drugs as first-line treatments. Myeloablative chemotherapy followed by ASCT can be offered to patients up to 65 years of age and to a subgroup of selected older patients with R/R PVRL. The risks of each therapeutic option must be considered at the time of the therapeutic decision along with the patient's characteristics. The results of a prospective study with single-agent pembrolizumab in patients with PCNSL, including a cohort of patients with PVRL, are pending (NCT03012620). Another major challenge in PVRL is the assessment of the therapeutic response. A prospective evaluation of the IL-10 level in the aqueous humor in addition to clinical and imaging ophthalmological examinations are currently the most promising feasible steps. 
The diagnosis of PVRL remains challenging because of the fragility of the lymphoma cells in the vitreous but is being improved by recent advances in cytokine assays and molecular biology. International collaborative prospective studies bringing together ophthalmologists, biologists and oncologists/hematologists are necessary to improve the therapeutic outcomes and to address the issue of therapeutic response criteria for PVRL. 


\section{REFERENCES}

1. Kluin PM, Deckert M, Ferry JA. Primary diffuse large B-cell lymphoma of the CNS. In: Swerdlow SH, Campo E, Harris NL, et Al, Eds. WHO Classification of Tumours of Haematopoietic and Lymphoid Tissues. Rev 4th Vo. Lyon, France; 2017:300-302.

2. Coupland SE, Damato B. Understanding intraocular lymphomas. Clin Exp Ophthalmol. 2008;36(6):564578. doi:10.1111/j.1442-9071.2008.01843.x

3. Soussain C, Houillier C, Ghesquieres H, et al. The French LOC Network for Primary CNS Lymphoma (PCNSL) Patients: What Can We Learn from a Large National Database? Blood. 2016;128(22):926. doi:10.1182/blood.V128.22.926.926

4. Chan C, Rubenstein JL, Coupland SE, et al. Primary Vitreoretinal Lymphoma: A Report from an International Primary Central Nervous System Lymphoma Collaborative Group Symposium. Oncologist. 2011;16(11):1589-1599. doi:10.1634/theoncologist.2011-0210

5. Montesinos-Rongen M, Brunn A, Bentink S, et al. Gene expression profiling suggests primary central nervous system lymphomas to be derived from a late germinal center B cell. Leukemia. 2008;22(2):400405. doi:10.1038/sj.leu.2405019

6. Schmitz R, Wright GW, Huang DW, et al. Genetics and Pathogenesis of Diffuse Large B-Cell Lymphoma. N Engl J Med. 2018;378(15):1396-1407. doi:10.1056/nejmoa1801445

7. Chapuy B, Stewart C, Dunford AJ, et al. Molecular subtypes of diffuse large B cell lymphoma are associated with distinct pathogenic mechanisms and outcomes. Nat Med. 2018;24(5):679-690. doi:10.1038/s41591-018-0016-8

8. Lam M, Touitou V, Choquet S, et al. Intravenous high-dose methotrexate based systemc therapy in the treatment of isolated primary vitreoretinal lymphoma: a LOC network study. Am. J. Hematol. Accepted

9. Grimm SA, Pulido JS, Jahnke K, et al. Primary intraocular lymphoma: An international primary central nervous system lymphoma collaborative group report. Ann Oncol. 2007;18(11):1851-1855. doi:10.1093/annonc/mdm340

10. Araujo I, Coupland SE. Primary vitreoretinal lymphoma-A review. Asia-Pacific J Ophthalmol. 2017;6(3):283-289. doi:10.22608/APO.2017150

11. Matet A, Behar-Cohen F, Cassoux N, Declèves X, Cisternino S. Retinal and choroidal cancers: Bloodretinal barriers considerations in ocular chemotherapy. In: Drug Efflux Pumps in Cancer Resistance Pathways: From Molecular Recognition and Characterization to Possible Inhibition Strategies in Chemotherapy. Elsevier; 2020:303-335. doi:10.1016/b978-0-12-816434-1.00010-3

12. Cassoux N, Giron A, Bodaghi B, et al. IL-10 measurement in aqueous humor for screening patients with suspicion of primary intraocular lymphoma. Investig Ophthalmol Vis Sci. 2007;48(7):3253-3259. doi:10.1167/iovs.06-0031

13. Touitou V, Daussy C, Bodaghi B, et al. Impaired Th1/Tc1 cytokine production of tumor-infiltrating lymphocytes in a model of primary intraocular B-cell lymphoma. Investig Ophthalmol Vis Sci. 2007;48(7):3223-3229. doi:10.1167/iovs.07-0008

14. Belhouachi N, Xochelli A, Boudjoghra M, et al. Primary vitreoretinal lymphomas display a remarkably restricted immunoglobulin gene repertoire. Blood Adv. 2020;4(7):1357-1366.

doi:10.1182/bloodadvances.2019000980

15. Yang Y, Shaffer AL, Emre NCT, et al. Exploiting Synthetic Lethality for the Therapy of ABC Diffuse Large B Cell Lymphoma. Cancer Cell. 2012;21(6):723-737. doi:10.1016/j.ccr.2012.05.024

16. Montesinos-Rongen M, Purschke FG, Brunn A, et al. Primary Central Nervous System (CNS) Lymphoma B Cell Receptors Recognize CNS Proteins. J Immunol. 2015;195(3):1312-1319.

doi:10.4049/jimmunol.1402341

17. Li Z, Mahesh SP, Shen DF, et al. Eradication of tumor colonization and invasion by a B cell-specific immunotoxin in a murine model for human primary intraocular lymphoma. Cancer Res. 2006;66(21):10586-10593. doi:10.1158/0008-5472.CAN-06-1981

18. Chan CC, Fischette M, Shen D, Mahesh SP, Nussenblatt RB, Hochman J. Murine model of primary intraocular lymphoma. Investig Ophthalmol Vis Sci. 2005;46(2):415-419. doi:10.1167/iovs.04-0869

19. Nguyen-Them L, Costopoulos M, Tanguy M-L, et al. The CSF IL-10 concentration is an effective diagnostic marker in immunocompetent primary CNS lymphoma and a potential prognostic biomarker in treatment-responsive patients. Eur J Cancer. 2016;61:69-76. doi:10.1016/j.ejca.2016.03.080

20. Cassoux N, Merle-Beral H, Leblond V, et al. Ocular end central nervous system lymphoma: Clinical features and diagnosis. Ocul Immunol Inflamm. 2000;8(4):243-250. doi:10.1076/ocii.8.4.243.6463 
21. Hoffman PM, McKelvie P, Hall AJ, Stawell RJ, Santamaria JD. Intraocular lymphoma: A series of 14 patients with clinicopathological features and treatment outcomes. Eye. 2003;17(4):513-521. doi:10.1038/sj.eye.6700378

22. Houillier $\mathrm{C}$, Soussain $\mathrm{C}$, Ghesquières $\mathrm{H}$, et al. Management and outcome of primary CNS lymphoma in the modern era: An LOC network study. Neurology. 2020;94(10):e1027-e1039. doi:10.1212/WNL.0000000000008900

23. Fardeau C, Lee CPL, Merle-Béral H, et al. Retinal Fluorescein, Indocyanine Green Angiography, and Optic Coherence Tomography in Non-Hodgkin Primary Intraocular Lymphoma. Am J Ophthalmol. 2009;147(5):886-894.e1. doi:10.1016/j.ajo.2008.12.025

24. Coupland SE. Analysis of intraocular biopsies. Dev Ophthalmol. 2012;49:96-116. doi:10.1159/000328266

25. Tang PH, Karkhur S, Nguyen QD. Obtaining undiluted vitreous sample using small gauge pars plana vitrectomy and air infusion. Am J Ophthalmol Case Reports. 2020;19(April):100768. doi:10.1016/j.ajoc.2020.100768

26. Coupland SE, Bechrakis NE, Anastassiou G, et al. Evaluation of vitrectomy specimens and chorioretinal biopsies in the diagnosis of primary intraocular lymphoma in patients with Masquerade syndrome. Graefe's Arch Clin Exp Ophthalmol. 2003;241(10):860-870. doi:10.1007/s00417-003-0749-y

27. Gonzales JA, Chan C. Biopsy techniques and yields in diagnosing primary intraocular lymphoma. Int Ophthalmol. 2007;27(4):241-250.

28. Davis JL. Intraocular lymphoma: A clinical perspective. Eye. 2013;27(2):153-162. doi:10.1038/eye.2012.250

29. Davis JL, Miller DM, Ruiz P. Diagnostic testing of vitrectomy specimens. Am J Ophthalmol. 2005;140(5). doi:10.1016/j.ajo.2005.05.032

30. Missotten T, Tielemans D, Bromberg JE, et al. Multicolor flowcytometric immunophenotyping is a valuable tool for detection of intraocular lymphoma. Ophthalmology. 2013;120(5):991-996. doi:10.1016/j.ophtha.2012.11.007

31. Chan CC. Molecular pathology of primary intraocular lymphoma. Trans Am Ophthalmol Soc. 2003;101:275-292. doi:10.1016/j.ajo.2004.02.095

32. Gorochov G, Parizot C, Bodaghi B, et al. Characterization of Vitreous B-Cell Infiltrates in Patients with Primary Ocular Lymphoma, Using CDR3 Size Polymorphism Analysis of Antibody Transcripts. Investig Ophthalmol Vis Sci. 2003;44(12):5235-5241. doi:10.1167/iovs.03-0035

33. Langerak AW, Groenen PJTA, Brüggemann M, et al. EuroClonality/BIOMED-2 guidelines for interpretation and reporting of Ig/TCR clonality testing in suspected lymphoproliferations. Leukemia. 2012;26(10):2159-2171. doi:10.1038/leu.2012.246

34. Whitcup SM, Stark-Vancs V, Wittes RE, et al. Association of interleukin 10 in the vitreous and cerebrospinal fluid and primary central nervous system lymphoma. Arch Ophthalmol (Chicago, III 1960). 1997;115(9):1157-1160. doi:10.1001/archopht.1997.01100160327010

35. Wolf LA, Reed GF, Buggage RR, Nussenblatt RB, Chan CC. Vitreous cytokine levels. Ophthalmology. 2003;110(8):1671-1672. doi:10.1016/S0161-6420(03)00811-X

36. Cassoux N, Merle-Beral H, Lehoang P, Herbort C, Chan CC. Interleukin-10 and intraocular-central nervous system lymphoma. Ophthalmology. 2001;108(3):426-427. doi:10.1016/s0161-6420(00)004012

37. Costopoulos M, Touitou V, Golmard JL, et al. ISOLD: A New Highly Sensitive Interleukin Score for Intraocular Lymphoma Diagnosis. Ophthalmology. 2016;123(7):1626-1628.

doi:10.1016/j.ophtha.2016.01.037

38. Dawson AC, Williams KA, Appukuttan B, Smith JR. Emerging diagnostic tests for vitreoretinal Iymphoma: a review. Clin Exp Ophthalmol. 2018;46(8):945-954. doi:10.1111/ceo.13304

39. Ngo VN, Young RM, Schmitz R, et al. Oncogenically active MYD88 mutations in human lymphoma. Nature. 2011;470(7332):115-121. doi:10.1038/nature09671

40. Raja H, Salomão DR, Viswanatha DS, Pulido JS. Prevalence of MYD88 L265P mutation in histologically proven, diffuse large B-cell vitreoretinal lymphoma. Retina. 2016;36(3):624-628. doi:10.1097/IAE.0000000000000996

41. Bonzheim I, Giese S, Deuter C, et al. High frequency of MYD88 mutations in vitreoretinal B-cell lymphoma: A valuable tool to improve diagnostic yield of vitreous aspirates. Blood. 2015;126(1):76-79. doi:10.1182/blood-2015-01-620518

42. Miserocchi E, Ferreri AJM, Giuffrè C, et al. Myd88 L265P Mutation Detection in the Aqueous Humor of Patients With Vitreoretinal Lymphoma. Retina. 2019;39(4):679-684. 
doi:10.1097/IAE.0000000000002319

43. Hiemcke-Jiwa LS, Ten Dam-Van Loon NH, Leguit RJ, et al. Potential Diagnosis of Vitreoretinal Lymphoma by Detection of MYD88 Mutation in Aqueous Humor with Ultrasensitive Droplet Digital Polymerase Chain Reaction. JAMA Ophthalmol. 2018;136(10):1098-1104. doi:10.1001/jamaophthalmol.2018.2887

44. Yonese I, Takase H, Yoshimori M, et al. CD79B mutations in primary vitreoretinal lymphoma: Diagnostic and prognostic potential. Eur J Haematol. 2019;102(2):191-196. doi:10.1111/ejh.13191

45. Minezaki T, Usui Y, Asakage M, et al. High-Throughput MicroRNA Profiling of Vitreoretinal Lymphoma: Vitreous and Serum MicroRNA Profiles Distinct from Uveitis. J Clin Med. 2020;9(6):1844. doi:10.3390/jcm9061844

46. Kakkassery V, Schroers R, Coupland SE, et al. Vitreous microRNA levels as diagnostic biomarkers for vitreoretinal lymphoma. Blood. 2017;129(23):3130-3133. doi:10.1182/blood-2017-01-765180

47. Lee J, Kim B, Lee $\mathrm{H}$, et al. Whole exome sequencing identifies mutational signatures of vitreoretinal lymphoma. Haematologica. 2020:haematol.2019.233783. doi:10.3324/haematol.2019.233783

48. Coupland SE, Heimann H, Bechrakis NE. Primary intraocular lymphoma: A review of the clinical, histopathological and molecular biological features. Graefe's Arch Clin Exp Ophthalmol.

2004;242(11):901-913. doi:10.1007/s00417-004-0973-0

49. Venkatesh R, Bavaharan B, Mahendradas P, Yadav NK. Primary vitreoretinal lymphoma: Prevalence, impact, and management challenges. Clin Ophthalmol. 2019;13:353-364. doi:10.2147/OPTH.S159014

50. Riemens A, Bromberg J, Touitou V, et al. Treatment strategies in primary vitreoretinal lymphoma: A 17center European collaborative study. JAMA Ophthalmol. 2015;133(2):191-197.

doi:10.1001/jamaophthalmol.2014.4755

51. Klimova A, Heissigerova J, Rihova $\mathrm{E}$, et al. Combined treatment of primary vitreoretinal lymphomas significantly prolongs the time to first relapse. Br J Ophthalmol. 2018;102(11):1579-1585.

doi:10.1136/bjophthalmol-2017-311574

52. Castellino A, Pulido JS, Johnston PB, et al. Role of systemic high-dose methotrexate and combined approaches in the management of vitreoretinal lymphoma: A single center experience 1990-2018. Am J Hematol. 2019;94(3):291-298. doi:10.1002/ajh.25350

53. Cheah CY, Milgrom S, Chihara D, et al. Intensive chemoimmunotherapy and bilateral globe irradiation as initial therapy for primary intraocular lymphoma. Neuro Oncol. 2016;18(4):575-581.

doi:10.1093/neuonc/nov253

54. Taoka K, Yamamoto G, Kaburaki T, Takahashi T, Araie M, Kurokawa M. Treatment of primary intraocular lymphoma with rituximab, high dose methotrexate, procarbazine, and vincristine chemotherapy, reduced whole-brain radiotherapy, and local ocular therapy. Br J Haematol. 2012;157(2):252-254. doi:10.1111/j.1365-2141.2011.08938.x

55. Hashida N, Nakai K, Saitoh N, Nishida K. Association between ocular findings and preventive therapy with onset of central nervous system involvement in patients with primary vitreoretinal lymphoma. Graefe's Arch Clin Exp Ophthalmol. 2014;252(4):687-693. doi:10.1007/s00417-014-2584-8

56. Akiyama $\mathrm{H}$, Takase $\mathrm{H}$, Kubo $\mathrm{F}$, et al. High-dose methotrexate following intravitreal methotrexate administration in preventing central nervous system involvement of primary intraocular lymphoma. Cancer Sci. 2016;107(10):1458-1464. doi:10.1111/cas.13012

57. Kaburaki T, Taoka K, Matsuda J, et al. Combined intravitreal methotrexate and immunochemotherapy followed by reduced-dose whole-brain radiotherapy for newly diagnosed B-cell primary intraocular lymphoma. Br J Haematol. 2017;179(2):246-255. doi:10.1111/bjh.14848

58. Hormigo A, Abrey L, Heinemann MH, DeAngelis LM. Ocular presentation of primary central nervous system lymphoma: Diagnosis and treatment. Br J Haematol. 2004;126(2):202-208. doi:10.1111/j.13652141.2004.05028.x

59. De Smet MD, Vancs VS, Kohler D, Solomon D, Chan CC. Intravitreal chemotherapy for the treatment of recurrent intraocular lymphoma. Br J Ophthalmol. 1999;83(4):448-451. doi:10.1136/bjo.83.4.448

60. Kim H, Csaky KG, Chan CC, et al. The pharmacokinetics of rituximab following an intravitreal injection. Exp Eye Res. 2006;82(5):760-766. doi:10.1016/j.exer.2005.09.018

61. Wong LJ, Desai RU, Jain A, et al. Surveillance for potential adverse events associated with the use of intravitreal bevacizumab for retinal and choroidal vascular disease. Retina. 2008;28(8):1151-1158. doi:10.1097/IAE.0b013e31817e100f

62. Fishburne BC, Wilson DJ, Rosenbaum JT, Neuwelt EA. Intravitreal methotrexate as an adjunctive treatment of intraocular lymphoma. Arch Ophthalmol (Chicago, III 1960). 1997;115(9):1152-1156. doi:10.1001/archopht.1997.01100160322009

63. Smith JR, Rosenbaum JT, Wilson DJ. Role of Intravitreal Methotrexate in the Management of Primary 
Central Nervous. Ophthalmology. 2002;109(9):1709-1716. doi:10.1016/s0161-6420(02)01125-9

64. Frenkel S, Hendler K, Siegal T, Shalom E, Pe'er J. Intravitreal methotrexate for treating vitreoretinal lymphoma: 10 Years of experience. Br J Ophthalmol. 2008;92(3):383-388. doi:10.1136/bjo.2007.127928

65. Zhou X, Zhou X, Shi H, et al. Reduced frequency of Intravitreal methotrexate injection lowers the risk of Keratopathy in Vitreoretinal lymphoma patients. BMC Ophthalmol. 2020;20(1):1-9.

doi:10.1186/s12886-020-01464-3

66. Pulido JS, Johnston PB, Nowakowski GS, Castellino A, Raja H. The diagnosis and treatment of primary vitreoretinal lymphoma: A review. Int J Retin Vitr. 2018;4(1):1-11. doi:10.1186/s40942-018-0120-4

67. Larkin KL, Saboo US, Comer GM, et al. Use of intravitreal rituximab for treatment of vitreoretinal lymphoma. Br J Ophthalmol. 2014;98(1):99-103. doi:10.1136/bjophthalmol-2013-304043

68. Hashida N, Ohguro N, Nishida K. Efficacy and Complications of Intravitreal Rituximab Injection for Treating Primary Vitreoretinal Lymphoma. Trans/ Vis Sci Technol. 2012;1(3):1. doi:10.1167/tvst.1.3.1

69. Shields CL, Sioufi K, Mashayekhi A, Shields JA. Intravitreal Melphalan for Treatment of Primary Vitreoretinal Lymphoma: A New Indication for an Old Drug. JAMA Ophthalmol. 2017;135(7):815-818. doi:10.1001/jamaophthalmol.2017.1810

70. Damato B, Bever GJ, Kim DJ, Afshar AR, Rubenstein JL. An audit of retinal lymphoma treatment at the University of California San Francisco. Eye. 2020;34(3):515-522. doi:10.1038/s41433-019-0539-3

71. Sen HN, Chan CC, Byrnes G, Fariss RN, Nussenblatt RB, Buggage RR. Intravitreal methotrexate resistance in a patient with primary intraocular lymphoma. Ocul Immunol Inflamm. 2008;16(1-2):29-33. doi:10.1080/09273940801899764

72. Fung AE, Rosenfeld PJ, Reichel E. The International Intravitreal Bevacizumab Safety Survey: Using the internet to assess drug safety worldwide. Br J Ophthalmol. 2006;90(11):1344-1349.

doi:10.1136/bjo.2006.099598

73. Grimm SA, McCannel CA, Omuro AMP, et al. Primary CNS lymphoma with intraocular involvement: International PCNSL Collaborative Group Report. Neurology. 2008;71(17):1355-1360.

doi:10.1212/01.wnl.0000327672.04729.8c

74. Kim MM, Dabaja BS, Medeiros J, et al. Survival outcomes of primary intraocular lymphoma a singleinstitution experience. Am J Clin Oncol Cancer Clin Trials. 2016;39(2):109-113.

doi:10.1097/COC.0000000000000028

75. Berenbom A, Davila RM, Lin HS, Harbour JW. Treatment outcomes for primary intraocular lymphoma: Implications for external beam radiotherapy. Eye. 2007;21(9):1198-1201. doi:10.1038/sj.eye.6702437

76. Kaushik M, Pulido JS, Schild SE, Stafford S. Risk of radiation retinopathy in patients with orbital and ocular lymphoma. Int J Radiat Oncol Biol Phys. 2012;84(5):1145-1150. doi:10.1016/j.ijrobp.2011.12.097

77. Bever GJ, Kim DJ, Afshar AR, Rubenstein JL, Damato BE. Therapeutic Vitrectomy As an Adjunct Treatment To Systemic Chemotherapy for Intraocular Lymphoma. Retin Cases Brief Rep. 2020;14(2):116-119. doi:10.1097/ICB.0000000000000668

78. De Smet MD, Stark-Vancs V, Kohler DR, Smith J, Wittes R, Nussenblatt RB. Intraocular levels of methotrexate after intravenous administration. Am J Ophthalmol. 1996;121(4):442-444.

doi:10.1016/S0002-9394(14)70444-1

79. Baumann MA, Ritch PS, Hande KR, Williams GA, Topping TM, Anderson T. Treatment of intraocular lymphoma with high-dose Ara-C. Cancer. 1986;57(7):1273-1275. doi:10.1002/1097-

0142(19860401)57:7<1273::aid-cncr2820570702>3.0.co;2-c

80. Batchelor TT, Kolak G, Ciordia R, Foster CS, Henson JW. High-dose methotrexate for intraocular lymphoma. Clin cancer Res an Off J Am Assoc Cancer Res. 2003;9(2):711-715.

81. Jahnke K, Wagner T, Bechrakis NE, et al. Pharmacokinetics and efficacy of ifosfamide or trofosfamide in patients with intraocular lymphoma. Ann Oncol. 2005;16(12):1974-1978. doi:10.1093/annonc/mdi409

82. de la Fuente MI, Alderuccio JP, Reis IM, et al. Bilateral radiation therapy followed by methotrexatebased chemotherapy for primary vitreoretinal lymphoma. Am J Hematol. 2019;94(4):455-460. doi:10.1002/ajh.25414

83. Soussain C, Merle-Béral H, Reux I, et al. A single-center study of 11 patients with intraocular lymphoma treated with conventional chemotherapy followed by high-dose chemotherapy and autologous bone marrow transplantation in 5 cases. Leuk Lymphoma. 1996;23(3-4):339-345. doi:10.3109/10428199609054837

84. Soussain C, Suzan F, Hoang-Xuan K, et al. Results of intensive chemotherapy followed by hematopoietic stem-cell rescue in 22 patients with refractory or recurrent primary CNS lymphoma or intraocular lymphoma. J Clin Oncol. 2001;19(3):742-749. doi:10.1200/JCO.2001.19.3.742

85. Soussain C, Choquet S, Fourme E, et al. Intensive chemotherapy with thiotepa, busulfan and 
cyclophosphamide and hematopoietic stem cell rescue in relapsed or refractory primary central nervous system lymphoma and intraocular lymphoma: A retrospective study of 79 cases.

Haematologica. 2012;97(11):1751-1756. doi:10.3324/haematol.2011.060434

86. van Besien K, Przepiorka D, Mehra R, et al. Impact of preexisting CNS involvement on the outcome of bone marrow transplantation in adult hematologic malignancies. J Clin Oncol Off J Am Soc Clin Oncol. 1996;14(11):3036-3042. doi:10.1200/JCO.1996.14.11.3036

87. Muldoon LL, Soussain C, Jahnke K, et al. Chemotherapy delivery issues in central nervous system malignancy: A reality check. J Clin Oncol. 2007;25(16):2295-2305. doi:10.1200/JCO.2006.09.9861

88. Baron M, Belin L, Cassoux N, et al. Temozolomide is effective and well tolerated in patients with primary vitreoretinal lymphoma. Blood. 2020;135(20):1811-1815. doi:10.1182/blood.2019003073

89. Ghesquieres $\mathrm{H}$, Chevrier $\mathrm{M}$, Laadhari $\mathrm{M}$, et al. Lenalidomide in combination with intravenous rituximab (REVRI) in relapsed/refractory primary CNS lymphoma or primary intraocular lymphoma: A multicenter prospective "proof of concept" phase II study of the French Oculo-Cerebral lymphoma (LOC) Network and. Ann Oncol. 2019;30(4):621-628. doi:10.1093/annonc/mdz032

90. Soussain $\mathrm{C}$, Choquet $\mathrm{S}$, Blonski $\mathrm{M}$, et al. Ibrutinib monotherapy for relapse or refractory primary CNS lymphoma and primary vitreoretinal lymphoma: Final analysis of the phase II 'proof-of-concept' iLOC study by the Lymphoma study association (LYSA) and the French oculo-cerebral lymphoma (LOC) net. Eur J Cancer. 2019;117(June 2017):121-130. doi:10.1016/j.ejca.2019.05.024

91. Rubenstein JL, Treseler PA, Stewart PJ. Regression of refractory intraocular large B-cell lymphoma with lenalidomide monotherapy. J Clin Oncol Off J Am Soc Clin Oncol. 2011;29(20):e595-7. doi:10.1200/JCO.2011.34.7252

92. Rubenstein JL, Geng H, Fraser EJ, et al. Phase 1 investigation of lenalidomide/rituximab plus outcomes of lenalidomide maintenance in relapsed CNS lymphoma. Blood Adv. 2018;2(13):1595-1607. doi:10.1182/bloodadvances.2017014845

93. Hernandez-Ilizaliturri FJ, Deeb G, Zinzani PL, et al. Higher response to lenalidomide in relapsed/refractory diffuse large B-cell lymphoma in nongerminal center B-cell-like than in germinal center B-cell-like phenotype. Cancer. 2011;117(22):5058-5066. doi:10.1002/cncr.26135

94. Wilson WH, Young RM, Schmitz R, et al. Targeting B cell receptor signaling with ibrutinib in diffuse large B cell lymphoma. Nat Med. 2015;21(8):922-926. doi:10.1038/nm.3884

95. Abrey LE, Batchelor TT, Ferreri AJM, et al. Report of an international workshop to standardize baseline evaluation and response criteria for primary CNS lymphoma. J Clin Oncol Off J Am Soc Clin Oncol. 2005;23(22):5034-5043. doi:10.1200/JCO.2005.13.524

96. Zhao H, Wang X, Mao Y, Peng X. Longitudinal observation of OCT imaging is a valuable tool to monitor primary vitreoretinal lymphoma treated with intravitreal injections of methotrexate. BMC Ophthalmol. 2020;20(1):1-8. doi:10.1186/s12886-019-1300-1

97. Stacey AW, Pulido JS. The Concept of Minimal Residual Disease in the Treatment and Staging of Vitreoretinal Lymphoma. Retina. 2020;40(7):1213-1214. doi:10.1097/IAE.0000000000002851

98. Cheson BD, Fisher RI, Barrington SF, et al. Recommendations for initial evaluation, staging, and response assessment of hodgkin and non-hodgkin lymphoma: The lugano classification. J Clin Oncol. 2014;32(27):3059-3067. doi:10.1200/JCO.2013.54.8800

99. Merle-Béral H, Davi F, Cassoux N, et al. Biological diagnosis of primary intraocular lymphoma. Br J Haematol. 2004;124(4):469-473. doi:10.1046/j.1365-2141.2003.04800.x

100. Jahnke K, Thiel E, Bechrakis NE, et al. Ifosfamide or trofosfamide in patients with intraocular lymphoma. J Neurooncol. 2009;93(2):213-217. doi:10.1007/s11060-008-9761-8 
Table 1. Comparison of the most common clinical manifestations of primary vitreoretinal lymphoma (PVRL) and uveitis

\begin{tabular}{|c|c|c|}
\hline & PVRL & Uveitis \\
\hline Ocular injection & No & Yes \\
\hline Anterior chamber inflammation & Quiet anterior chamber & Flare or cells \\
\hline Keratic precipitates & $\begin{array}{l}\text { No or some cellular gray diffuse } \\
\text { keratic precipitates }\end{array}$ & Yes (granulomatous or not) \\
\hline Synechia & No & Possible \\
\hline Vitreous & Cellular & Cellular and albuminous \\
\hline Retina & Subretinal or retinal infiltration & $\begin{array}{l}\text { Vasculitis, retinal necrosis, } \\
\text { subretinal fluid, macular edema }\end{array}$ \\
\hline Choroid & No infiltration* & Possible infiltration (granuloma) \\
\hline $\begin{array}{l}\text { Optical coherence tomography } \\
\text { (OCT) }\end{array}$ & Subretinal deposits & Macular edema, subretinal fluid \\
\hline Fluorescein angiography & $\begin{array}{l}\text { Hypofluorescent spots (active } \\
\text { lesions), window defects (scar), } \\
\text { retinal pigmented epithelium } \\
\text { disturbances corresponding to a } \\
\text { leopard skin pattern }\end{array}$ & $\begin{array}{l}\text { Papillitis, vasculitis, cystoid macular } \\
\text { edema, inflammatory capillaropathy, } \\
\text { hypo or hyperfluorescent lesions, } \\
\text { subretinal fluid, pinpoint }\end{array}$ \\
\hline
\end{tabular}

*Lymphomatous infiltration of the choroid is suggestive of a primary choroidal lymphoma (mainly MALT [mucosa-associated lymphoid tissue] lymphoma ) or a secondary choroidal involvement of systemic lymphoma ${ }^{2}$ 
Table 2. Procedures for vitreous sampling and analysis

\begin{tabular}{|c|c|c|c|c|}
\hline Before sampling & $\begin{array}{l}\text { Technique for } \\
\text { sampling }\end{array}$ & Eye samples & \multicolumn{2}{|l|}{ Analysis of sample } \\
\hline \multirow{4}{*}{$\begin{array}{l}\text { Discussion with the } \\
\text { pathologist for prompt } \\
\text { processing of the } \\
\text { sample }\end{array}$} & \multirow{4}{*}{$\begin{array}{l}\text { Gentle diagnostic } \\
\text { vitrectomy } \\
\text { (low cutting speed) }\end{array}$} & \multirow[t]{2}{*}{ Pure vitreous } & $\begin{array}{l}\text { Cytology } \\
\text { Immunocytochemistry, flow cytometry } \\
\text { Preferably without a fixative and processed } \\
\text { within } 2 \text { hours after the reception. If a fixative } \\
\text { is required: HOPE fixation is preferred }\end{array}$ & $\begin{array}{l}\text { At least } 4 \text { cytospins } \\
2 \text { cytospots for cytomorphological evaluation } \\
\text { after MGG coloration } \\
2 \text { cytospots for immunocytochemistry } \\
\text { Use the total amount of the available material }\end{array}$ \\
\hline & & & Cytokines (IL-10 and IL-6) without a fixative & $\begin{array}{l}\text { Storage at }-80^{\circ} \mathrm{C} \\
\text { Measure of cytokine levels in thawed samples }\end{array}$ \\
\hline & & & \multicolumn{2}{|c|}{$\begin{array}{l}\text { Preferably without a fixative and processed within } 2 \text { hours after the reception. If fixative is } \\
\text { required: HOPE fixation }\end{array}$} \\
\hline & & $\begin{array}{l}\text { Vitreous diluted in BSS } \\
\text { during the surgical } \\
\text { procedure }\end{array}$ & $\begin{array}{l}\text { Immunocytochemistry, flow cytometry, } \\
\text { molecular biology }\end{array}$ & $\begin{array}{l}2 \text { cytospots for cytomorphological evaluation } \\
\text { after MGG coloration } \\
2 \text { cytospots for immunocytochemistry } \\
\text { Remaining slides stored at }-30^{\circ} \mathrm{C}\end{array}$ \\
\hline
\end{tabular}

HOPE: Herpes/glutamic acid buffer-mediated Organic solvent Protection Effect; MGG: May-Grünwald-Giemsa; BSS: Balanced Salt Solution Adapted from Coupland et al. ${ }^{24}$, Gonzales et al. ${ }^{27}$ and Merle-Béral et al. ${ }^{99}$. 
Table 3. Available pharmacokinetic data of drugs in the ocular compartments

\begin{tabular}{|c|c|c|c|c|c|}
\hline Ref & Drug & Route & $\mathrm{N}$ & Dose & Results \\
\hline Baumann $^{79}$ & Cytarabine & IV & 1 & $3 \mathrm{~g} / \mathrm{m}^{2}$ & $\begin{array}{l}\text { At } 90 \text { min after perfusion: } \\
\mathrm{C}[\text { vitreous] }=22 \mu \mathrm{M} ; \\
\mathrm{C} \text { [aqueous humor] }=31 \mu \mathrm{M} ; \\
\mathrm{C}[\text { serum }]=11 \mu \mathrm{M}\end{array}$ \\
\hline Batchelor $^{80}$ & Methotrexate* & IV & 9 & $\begin{array}{l}8 \mathrm{~g} / \mathrm{m}^{2} \text { in a } 4- \\
\text { hour perfusion }\end{array}$ & $\begin{array}{l}\text { At } 4 \text { hours after perfusion: } \\
\mathrm{C}[\text { vitreous] }>1 \mu \mathrm{M}\end{array}$ \\
\hline \multirow[t]{2}{*}{ Jahnke $^{81}$} & Ifosfamide & IV & 6 & $1.5-2 \mathrm{~g} / \mathrm{m}^{2}$ & $\begin{array}{l}\text { At the end of perfusion } \\
\mathrm{C}^{* *} \text { [aqueous humor] }=0.32- \\
1.56 \mu \mathrm{M} \text { in } 6 \text { patients }\end{array}$ \\
\hline & Trofosfamide & Oral & 4 & $150-400 \mathrm{mg}$ & $\begin{array}{l}\mathrm{C}^{* *}[\text { aqueous humor] }=7.2 \mu \mathrm{M} \\
\text { in one patient } 4 \text { hours after } \\
\text { ingestion }\end{array}$ \\
\hline De Smet ${ }^{78}$ & Methotrexate* & IVT & 1 & $\begin{array}{l}400 \mu \mathrm{g}(4 \\
\mathrm{mg} / \mathrm{mL})\end{array}$ & $\begin{array}{l}\mathrm{C}[\text { vitreous] } \approx 1 \mu \mathrm{M} 5 \text { days after } \\
\text { IVT }\end{array}$ \\
\hline $\mathrm{Kim}^{60}$ & Rituximab & IVT & $\begin{array}{l}16 \\
\text { rabbits }\end{array}$ & $1 \mathrm{mg} / 0.1 \mathrm{ml}$ & $\begin{array}{l}\text { Half-life: } 4.7 \text { days } \\
\text { Clearance from the aqueous } \\
\text { humor: } 1.2 \mathrm{~mL} / \mathrm{min}\end{array}$ \\
\hline
\end{tabular}

IV: intravenous; C: concentration; IVT: intravitreal injection; * the minimal effective tumoricidal (cytotoxic) level is $1 \mu \mathrm{M}$; ** 4-OH metabolites were dosed 
Table 4. Characteristics and therapeutic results of retrospective and prospective studies of first-line treatment for primary vitreoretinal lymphoma

\begin{tabular}{|c|c|c|c|c|c|c|}
\hline Ref & $\begin{array}{l}\text { Type of study } \\
\text { Time span }\end{array}$ & $\mathrm{N}$ & $\begin{array}{l}\text { Median age } \\
\text { (range) }\end{array}$ & Type of treatment & Survival & CNS events \\
\hline Grimm $^{9}$ & $\begin{array}{l}\text { International } \\
\text { multicenter } \\
\text { retrospective study } \\
1977-2005\end{array}$ & 83 & $63(24-85)$ & $\begin{array}{l}\text { Local } \\
\text { (IVT MTX or ORT): } N=23 \\
\text { Systemic + local } *: N=53\end{array}$ & $\begin{array}{l}\text { Median PFS = } 29.6 \\
\text { months } \\
\text { Median OS = } 58 \text { months } \\
\text { Median FU of surviving } \\
\text { patients = } 32 \text { months } \\
\text { No difference among } \\
\text { treatment groups }\end{array}$ & $\begin{array}{l}\text { CNS relapse in } 29 \\
\text { patients (35\%) } \\
\text { No difference among } \\
\text { treatment group }\end{array}$ \\
\hline Riemens $^{50}$ & $\begin{array}{l}\text { European } \\
\text { multicenter } \\
\text { retrospective study } \\
1991-2012\end{array}$ & 78 & $58(39-86)$ & $\begin{array}{l}\text { Local } \\
\text { (IVT MTX } \pm \text { Ritux or ORT): } \mathrm{N}=31 \\
\text { Extensive: } \mathrm{N}=21 \\
\text { Local and extensive } *: \mathrm{N}=23\end{array}$ & $\begin{array}{l}\text { PFS: NA } \\
5-y \text { OS = } 68 \% \text { when no } \\
\text { CNS relapse occurred } \\
5-y \text { OS = 35\% when CNS } \\
\text { relapse occurred }\end{array}$ & $\begin{array}{l}\text { Median CNS-free survival } \\
=47 \text { months } \\
\text { No difference between } \\
\text { treatment groups }\end{array}$ \\
\hline Klimova $^{51}$ & $\begin{array}{l}\text { Retrospective single- } \\
\text { center study } \\
2004-2016\end{array}$ & 10 & $59(48-71)$ & $\begin{array}{l}\text { Local (IVT MTX): } \mathrm{N}=3 \\
\text { Local + IV MTX-based: } \mathrm{N}=7\end{array}$ & $\begin{array}{l}\text { Median PFS not reached } \\
\text { in the local + IV treatment } \\
\text { group } \\
\text { NA in the local treatment } \\
\text { group } \\
P=0.032\end{array}$ & NA \\
\hline Castellino ${ }^{52}$ & $\begin{array}{l}\text { Retrospective single- } \\
\text { center study } \\
1990-2018\end{array}$ & $32 * * *$ & $67(36-84)$ & $\begin{array}{l}\text { Local } \\
\text { (IVT MTX } \pm \text { Ritux or ORT): } N=17 \\
\text { IV } \$ N=7 \\
\text { Local }+ \text { IV: } N=8\end{array}$ & $\begin{array}{l}\text { PFS: NA } \\
\text { FFS: } \\
\text { - Local: } 1.8 \mathrm{y} \\
\text { - IV: } 3.2 \mathrm{y} \\
\text { - } \quad \text { Local + IV: NR } \\
\mathrm{P}=0.002\end{array}$ & $\begin{array}{l}\text { Median CNS-free } \\
\text { survival: NR } \\
\text { CNS relapse }=37 \% \text { with a } \\
\text { median FU }=2.8 \text { y }\end{array}$ \\
\hline Cheah $^{53}$ & $\begin{array}{l}\text { Retrospective single- } \\
\text { center study } \\
\text { 2007-NA }\end{array}$ & 11 & $66(48-72)$ & $\begin{array}{l}\text { Local + IV } \\
\text { RMPV + } 36 \text { Gy binocular + HD-AraC }\end{array}$ & Median PFS $=3.8 \mathrm{y}$ & $\begin{array}{l}\text { 4-year cumulative } \\
\text { incidence of CNS } \\
\text { progression }=58 \%\end{array}$ \\
\hline
\end{tabular}




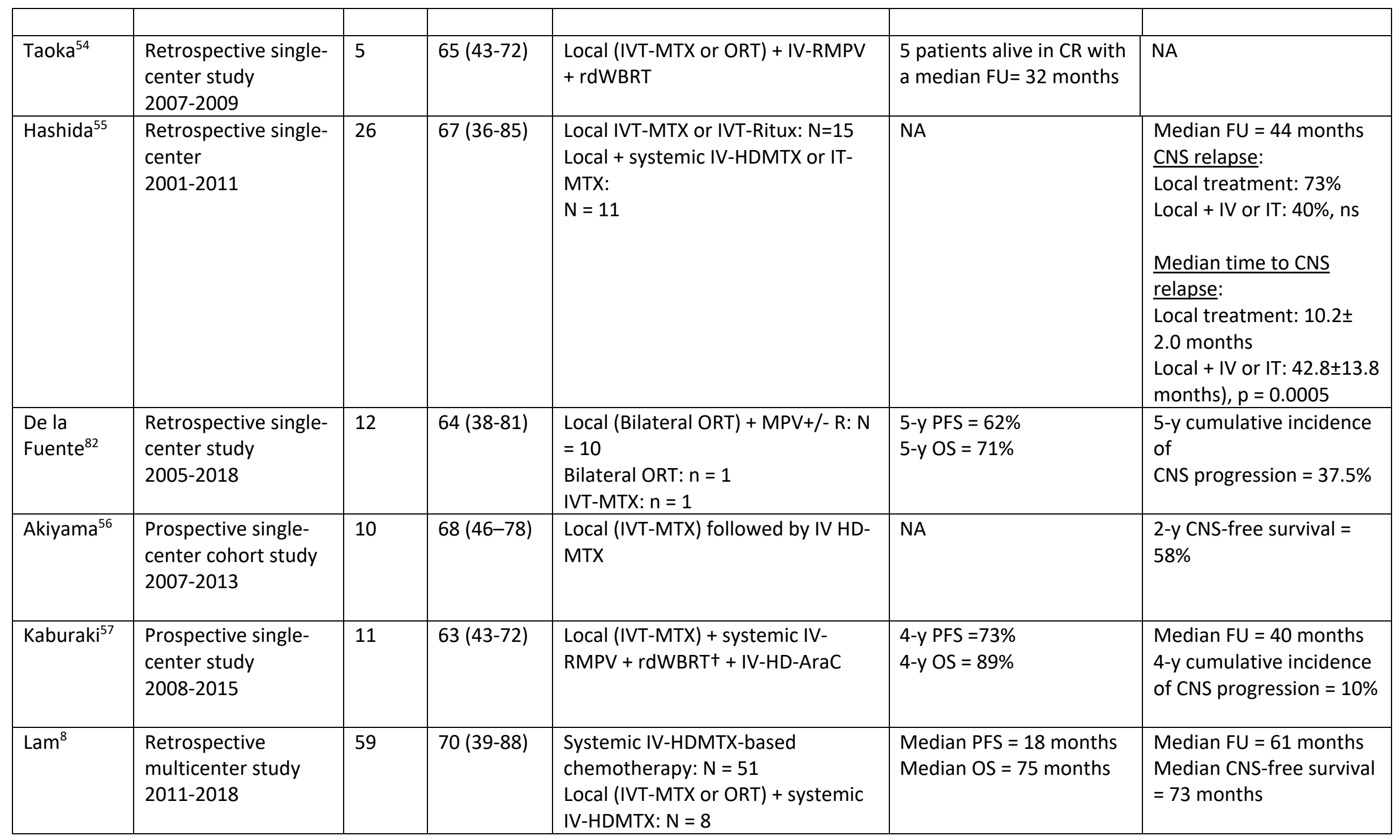


PVRL: primary vitreoretinal lymphoma; PFS: progression-free survival; FFS: failure free survival; OS: overall survival; CNS: central nervous system; MTX: methotrexate; IVT: intravitreal; IT: intrathecal; HD: high dose; IC + ASCT: intensive chemotherapy and autologous stem cell transplantation; IV: intravenous; Ritux: rituximab; ORT: ocular radiotherapy; NA: not available; ns: not significant; NR: not reached;

*Systemic + local treatment included various combinations of systemic chemotherapy, ocular chemotherapy, whole brain

radiotherapy, and ocular radiotherapy. Systemic chemotherapy was methotrexate-based therapy in 37 patients (70\%).

** Local treatment included local radiotherapy and IVT MTX and/or rituximab. Extensive treatment regimens were heterogeneous and included HD MTX or aracytine $(n=40)$, whole-brain radiotherapy $(n=6)$, and peripheral blood stem cell transplantation $(n=4)$.

*** In this paper, 33 patients had PVRL, 18 with concurrent intraocular and CNS or systemic disease and 18 with secondary VRL. One patient with PVRL did not receive any treatment. Only patients with PVRL and treated were considered in this review. \$Detailed descriptions of the systemic treatments administered to the subgroup of patients with PVRL are not available. MPV: HD-MTX, procarbazine, vincristine; RMPV: rituximab, HD-MTX, procarbazine, vincristine; FU = follow-up; rdWBRT: reduced dose whole brain radiotherapy (23.4 Gy); †IV chemotherapy and rdWBRT were administered to patients who achieved a CR; AraC: cytarabine; NS: not significant 
Table 5. Characteristics and therapeutic results of retrospective and prospective studies of relapsed or refractory primary vitreoretinal lymphoma

\begin{tabular}{|c|c|c|c|c|c|c|c|}
\hline Ref & Type of study & $\mathrm{N}$ & $\begin{array}{l}\text { Median } \\
\text { age } \\
\text { (range) }\end{array}$ & Treatment & Responses & CNS relapse & Survival \\
\hline \multicolumn{8}{|c|}{ Systemic treatments } \\
\hline Rubenstein $^{92}$ & $\begin{array}{l}\text { Prospective } \\
\text { phase I trial }\end{array}$ & $5 *$ & $\begin{array}{l}66 \\
(47-79)\end{array}$ & $\begin{array}{l}\text { Lenalidomide (10-30 mg/day } \\
21 \text { days } / 28) \\
\pm \text { Ritux iv + intraventricular }\end{array}$ & $\begin{array}{l}1 \mathrm{CR} ; 3 \mathrm{PR} ; 1 \\
\mathrm{SD}\end{array}$ & NA & PFS: $1.75,6,9,21$ and $48+$ \\
\hline Ghesquieres $^{89}$ & $\begin{array}{l}\text { Prospective } \\
\text { multicenter } \\
\text { phase II trial }\end{array}$ & $17^{* *}$ & $\begin{array}{l}69 \\
(46-86)\end{array}$ & $\begin{array}{l}\text { Ritux iv }\left(375 \mathrm{mg} / \mathrm{m}^{2}\right) \\
\text { Lenalidomide }(20-25 \mathrm{mg} / \text { day } \\
21 \text { days } / 28)\end{array}$ & $C R=35 \%$ & $\begin{array}{l}\mathrm{NA} \\
\mathrm{mFU}=19 \text { months }\end{array}$ & $\begin{array}{l}\text { Median PFS = } 9.2 \text { months } \\
\text { Median OS not reached }\end{array}$ \\
\hline Soussain 90 & $\begin{array}{l}\text { Prospective } \\
\text { multicenter } \\
\text { phase II trial }\end{array}$ & $14^{* *}$ & $\begin{array}{l}67 \\
(47-82)\end{array}$ & Ibrutinib (560 mg/day) & $C R=50 \%$ & $\begin{array}{l}\mathrm{N}=1(\mathrm{mFU}=26 \\
\text { months) }\end{array}$ & Median PFS = 23 months \\
\hline Baron $^{88}$ & $\begin{array}{l}\text { Retrospective } \\
\text { multicenter } \\
\text { study }\end{array}$ & 21 & $\begin{array}{l}75 \\
(35-90)\end{array}$ & $\begin{array}{l}\text { Temozolomide }(150 \\
\left.\mathrm{mg} / \mathrm{m}^{2} / \text { day } \times 5\right)\end{array}$ & $\mathrm{CR}=71 \%$ & $\begin{array}{l}\mathrm{N}=5 \\
\text { (mFU = } 42 \text { months) }\end{array}$ & PFS $=12$ months \\
\hline Jahnke ${ }^{100}$ & $\begin{array}{l}\text { Retrospective } \\
\text { study }\end{array}$ & 10 & NA & $\begin{array}{l}\text { Ifosfamide IV or trofosfamide } \\
\text { PO }\end{array}$ & $\begin{array}{l}\text { CR: } N=9 \\
\text { PR: } N=1\end{array}$ & $N=2$ & $\begin{array}{l}\mathrm{PFS}=18 \mathrm{~m} \\
\mathrm{OS}=32 \mathrm{~m}\end{array}$ \\
\hline Soussain $^{83+}$ & $\begin{array}{l}\text { Retrospective } \\
\text { study }\end{array}$ & 5 & NA & $\mathrm{TBC}+\mathrm{ASCT}$ & CR: $N=5$ & $N=0$ & 3 patients alive at $14,14,15$ months \\
\hline Soussain $^{84+}$ & $\begin{array}{l}\text { Retrospective } \\
\text { study }\end{array}$ & $11^{*}$ & $\begin{array}{l}53 \\
(27-64)\end{array}$ & $\mathrm{TBC}+\mathrm{ASCT}$ & $\begin{array}{l}\text { CR: } N=9 \\
\text { PR: } N=2\end{array}$ & $\begin{array}{l}\mathrm{N}=0 \\
\mathrm{mFU}=41.5 \\
\text { months }\end{array}$ & $\begin{array}{l}7 \text { patients alive with a CR at } 18,28, \\
41,45,49,62,69, \text { and } 70 \text { months }\end{array}$ \\
\hline Soussain $^{85}$ & $\begin{array}{l}\text { Retrospective } \\
\text { study }\end{array}$ & $11^{*}$ & $\begin{array}{l}52 \\
(23-67)\end{array}$ & $\mathrm{TBC}+\mathrm{ASCT}$ & $\begin{array}{l}\text { NA for the PV } \\
\text { patients }\end{array}$ & L subgroup of & $\begin{array}{l}\text { 5-y PFS = } 50 \% \text { (no significant } \\
\text { difference between patients with } \\
\text { PVRL and PCNSL) }\end{array}$ \\
\hline
\end{tabular}

CNS: central nervous system; IV: intravenous; PO: oral route; CR: complete response; PR: partial response; PFS: progression-free survival; OS: overall survival; TBC: thiotepa (750 mg/m²)-busulfan ( $8 \mathrm{mg} / \mathrm{kg})$-cyclophosphamide (120 mg/kg); ASCT: autologous stem cell transplantation; mFU: median followup; iv: intravenous 
†: These two studies did not include the same patients; *: number of patients with intraocular lymphoma (isolated intraocular relapse of a primary CNS lymphoma $n=3$; intraocular and brain relapse of a systemic lymphoma $n=1$; intraocular and brain relapse of a primary CNS lymphoma $n=1$ ); ** number of patients included in the studies with isolated intraocular disease involvement (R/R PVRL, and intraocular relapse of PCNSL)

NA: not available 
Figure 1. Schema of the anatomy of the eye and anatomical classification of intraocular lymphomas (IOLs).

IOLs can occur in the uveal tract (iris, ciliary body and choroid) as a primary (mainly MALT [mucosa-associated lymphoid tissue] lymphoma) or secondary (to systemic lymphoma) form.

IOLs that occur into the vitreous body, the retina or in rare cases the optic nerve are called vitreoretinal lymphomas (VRLS). VRLs are subdivided into primary vitreoretinal lymphomas (PVRLs), ocular involvement of primary central nervous system lymphoma (PCNSL) and secondary lymphoma from a systemic diffuse large B-cell lymphoma (DLBCL). The typical localization of lymphoma cells in the case of PVRL is represented by the small yellow circles drawn on the picture. Image A: Slit-lamp examination of an eye affected by PVRL showing the infiltration of lymphoma cells in the anterior vitreous and along the vitreous fibrils. Image B: Optical coherence tomography (OCT) image of the retina illustrating the infiltration of lymphoma cells into the subretinal space between the retinal pigmented epithelium (yellow arrow) and the Bruch's membrane (white arrow) or into the vitreous body.

Figure 2. Ophthalmological findings and multimodal imaging of primary vitreoretinal lymphoma. A: Slit-lamp examination showing a quiet anterior chamber with no protein flare and some cellular gray diffuse keratic precipitates (white arrows). B: A clump of lymphoma cells is visible in the slit-lamp examination in the anterior vitreous or along the vitreous fibrils (yellow arrow). C: At diagnosis, a fundus examination reveals only subtle small yellowish retinal lesions (white arrow). D: The (sub)retinal lesions detected at diagnosis are more extended and multifocal (yellow arrow) (composite color fundus photograph, photos merged together with built-in camera software) E: Retinal photograph showing creamcolored subretinal deposits (white stars). F: Infrared photograph of the same patient illustrated in $\mathrm{E}$, showing hyperreflective lesions corresponding to the lesions visible in $\mathrm{E}$ (white stars). G: Fluorescein angiography of the same patient illustrated in E, showing the lymphoid infiltration as dark spots masking the underlying fluorescence of the choroid (white stars). Retinal pigmented epithelium (RPE) alterations appear as hyperfluorescent areas due to window effects (yellow arrow). $\mathrm{H}$ : Indocyanine angiography of the same patient illustrated in $\mathrm{E}$, poorly contributive; hypocyanescent lesions are visualized. I: Fundus picture showing patchy yellowish subretinal lesions (white star). J: OCT image of the retina along the white line in I showing subretinal hyperreflective deposits of lymphoma cells (white star) that are located between the RPE (yellow arrow) and the Bruch membrane (white arrow).

\section{Figure 3. Typical cytology of vitreoretinal lymphoma. Reconstruction from 4 fields of the same cytospin.}

A: May-Grünvald-Giemsa staining of a diluted vitrectomy specimen. Cytospin shows 2 large lymphoid cells with a basophilic cytoplasm and irregular nuclei with several nucleoli corresponding to large lymphomatous cells. A small reactive lymphocyte (insert picture) was visible on another field of the same cytospin.

B: Immunochemistry with an anti-CD3 antibody and APAAP staining showing the negativity of a large lymphoma cell and the positivity of a reactive lymphocyte (inset picture). These two cells were identified in two different fields on the same cytospin 
C: Immunochemistry with an anti-CD20 antibody and APAAP (Alkaline Phosphatase-AntiAlkaline Phosphatase) staining showing the positivity of a large lymphoma cell and the negativity of a reactive lymphocyte (inset picture). These two cells were identified in two different fields on the same cytospin

Figure 4. Interleukin levels in case of a clinical suspicion of primary vitreoretinal Iymphoma. A. IL-10 (interleukin 10) and IL-6 levels in the aqueous humor and vitreous for PVRL screening and diagnosis. In the aqueous humor, an absolute level of IL-10 $\geq 50 \mathrm{pg} / \mathrm{mL}$ and IL-10/IL-6 ratio greater than 1 is suggestive of PVRL (IL-10 cutoff: sensitivity 89\%, specificity 93\%). In patients with uveitis, the level of IL-10 is low and IL-10/IL-6 ratio is lower than 1. In patients with an infectious disease, the IL-10 level might exceed $50 \mathrm{pg} / \mathrm{mL}$, but the IL-6 level might also be higher than $50 \mathrm{pg} / \mathrm{mL}$ : the IL-10/IL-6 ratio is lower than 1 . In the vitreous, the absolute level of IL-10 $\geq 400 \mathrm{pg} / \mathrm{mL}$ and IL-10/IL- 6 ratio greater than 1 are also suggestive of PVRL (IL-10 cutoff: sensitivity 80\%, specificity 99\%). From Cassoux et al. Investigative Ophthalmology and Visual Science, 2007; Chan et al. American Journal of Ophthalmology, 1995.

B. ISOLD score. The Interleukin Score for intraOcular Lymphoma Diagnosis (ISOLD) score is a probability score for the diagnosis of PVRL based on a mathematic formula combining both IL-10 and IL-6 levels in vitreous or aqueous samples with high sensitivity and specificity (93\% and 95\% respectively). From Costopoulos et al., Ophthalmology, 2016.

Figure 5. Clinical evaluation of the response to treatment of primary vitreoretinal lymphoma. A: Retinal photograph of a subretinal yellowish lesion corresponding to the lymphoma lesion before treatment (white arrow). B: OCT (Optical Coherence Tomography) image of the lesion described in A showing hyperreflective subretinal deposits (white star). C: After systemic treatment, the subretinal lesion completely disappeared in the retinal photograph (yellow arrow). D: In the OCT image, the subretinal deposits also disappeared (yellow star). E: In another patient, composite color fundus photograph (photos merged together with built-in camera software) shows a diffuse subretinal yellowish lesions corresponding to (sub)retinal infiltration by lymphoma cells captured before treatment (white arrow). In this patient, the vitreous was clear and free of visible lymphoma cells. The vitreous levels of IL-10 and IL- 6 were low $(36 \mathrm{pg} / \mathrm{mL}$ and $6 \mathrm{pg} / \mathrm{mL}$ respectively). A retinal biopsy was performed in the area of the white star to assess the diagnosis in this patient with pure retinal lymphoma. F: composite color fundus photograph (photos merged together with built-in camera software.) of patient illustrated in E, after two courses of systemic chemotherapy (rituximab, high-dose methotrexate, procarbazine, and vincristine), showing the disappearance of most of the lesions (yellow arrow). The residual active lesions (blue arrows) disappeared after subsequent courses of chemotherapy. The scar from the retinal biopsy performed during diagnostic vitrectomy is visible in the nasal side of the optic nerve (yellow star). 


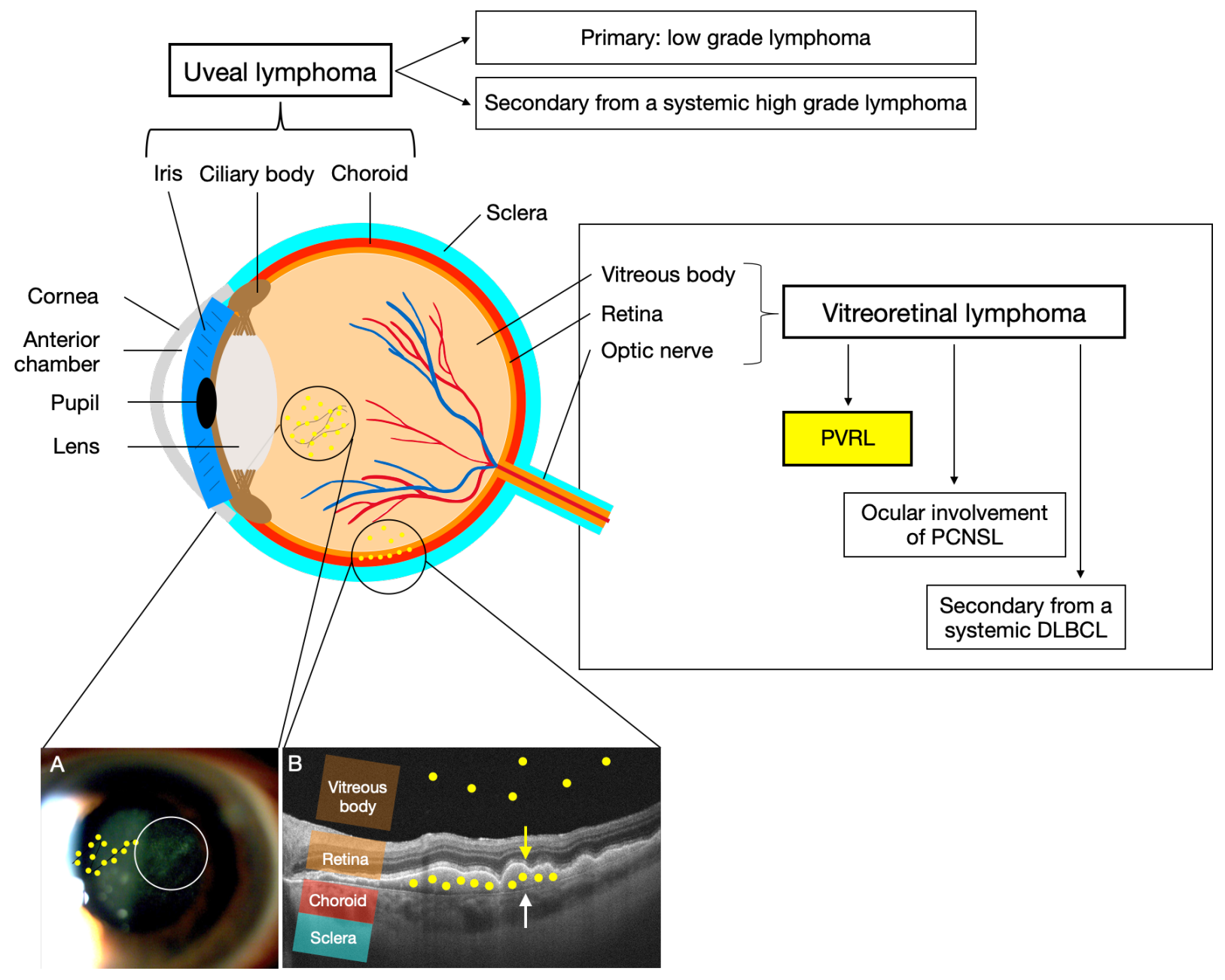




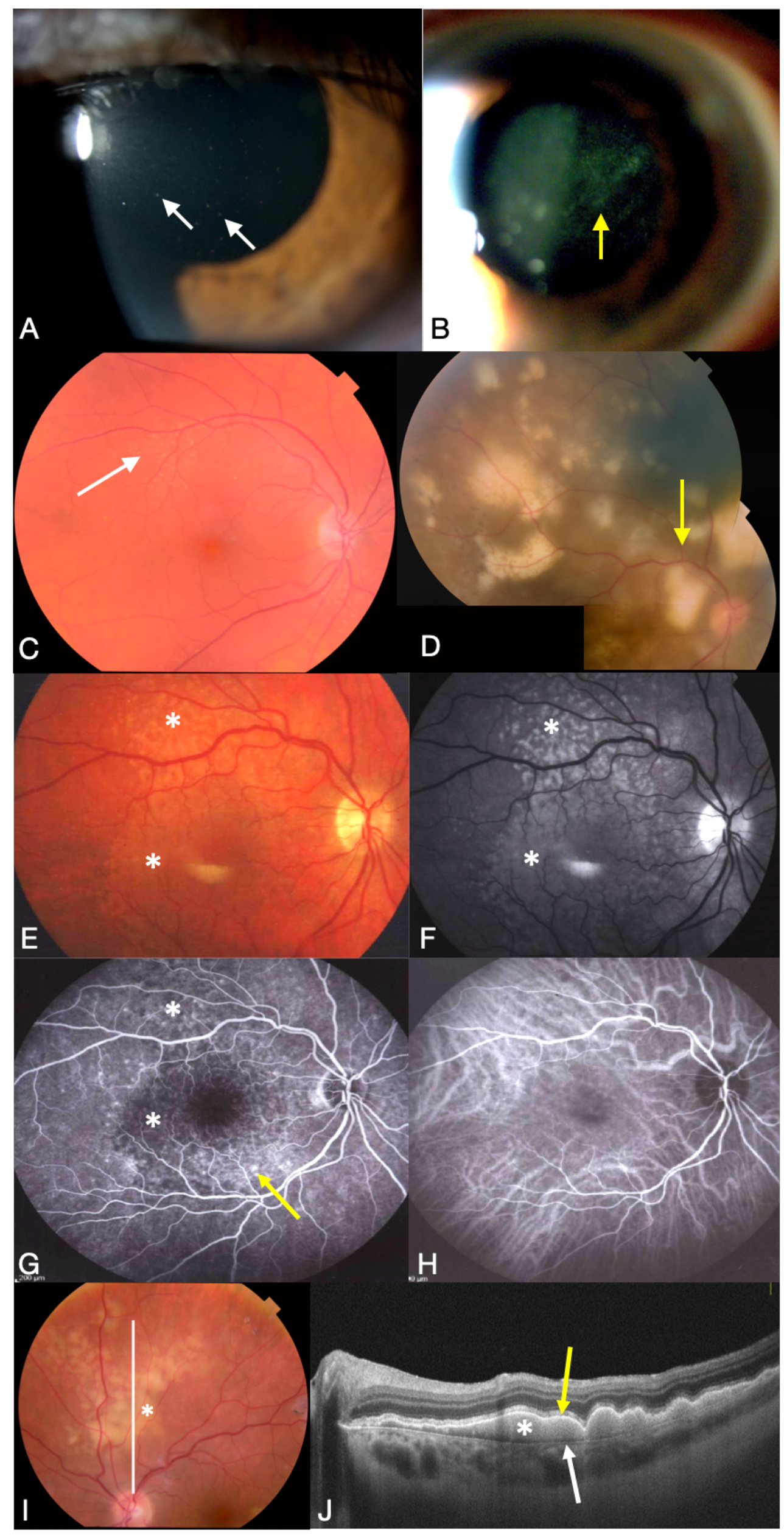




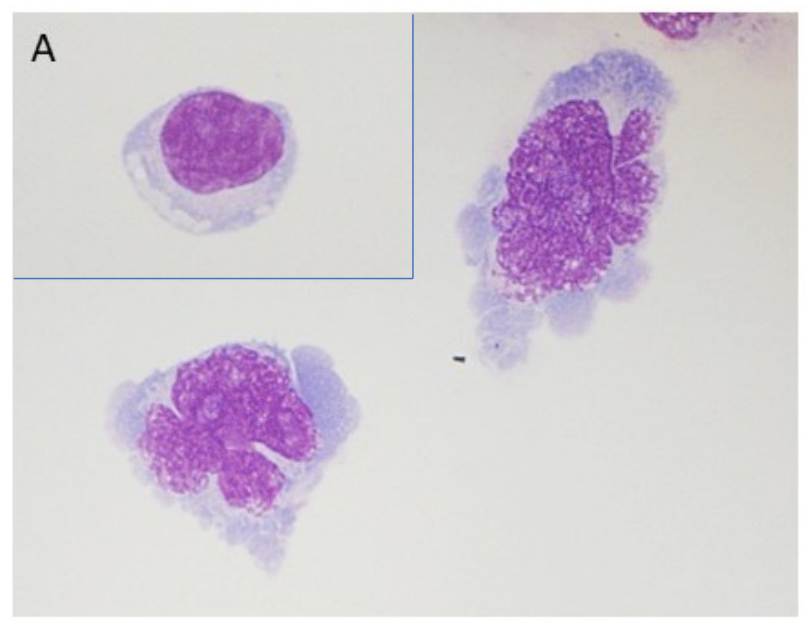
A- MGG
B- $C D 3$
C- CD20
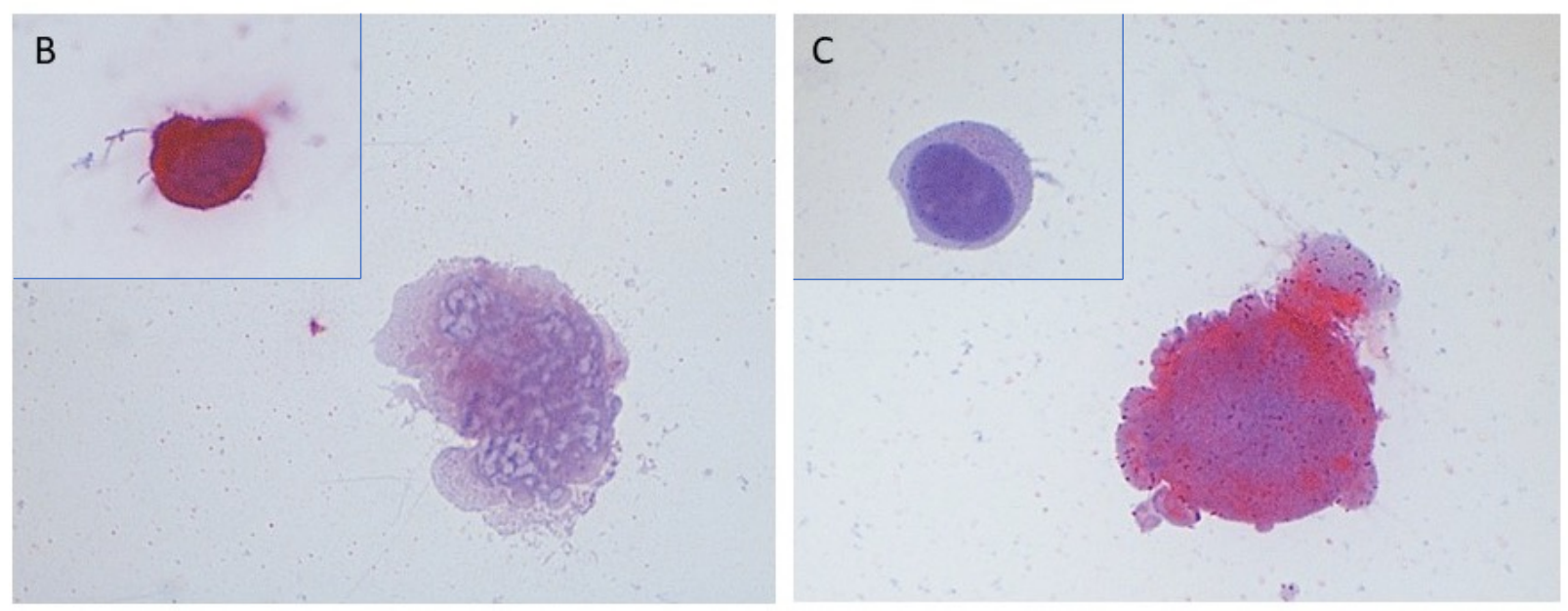
A.

IL dosage in aqueous from anterior chamber tap

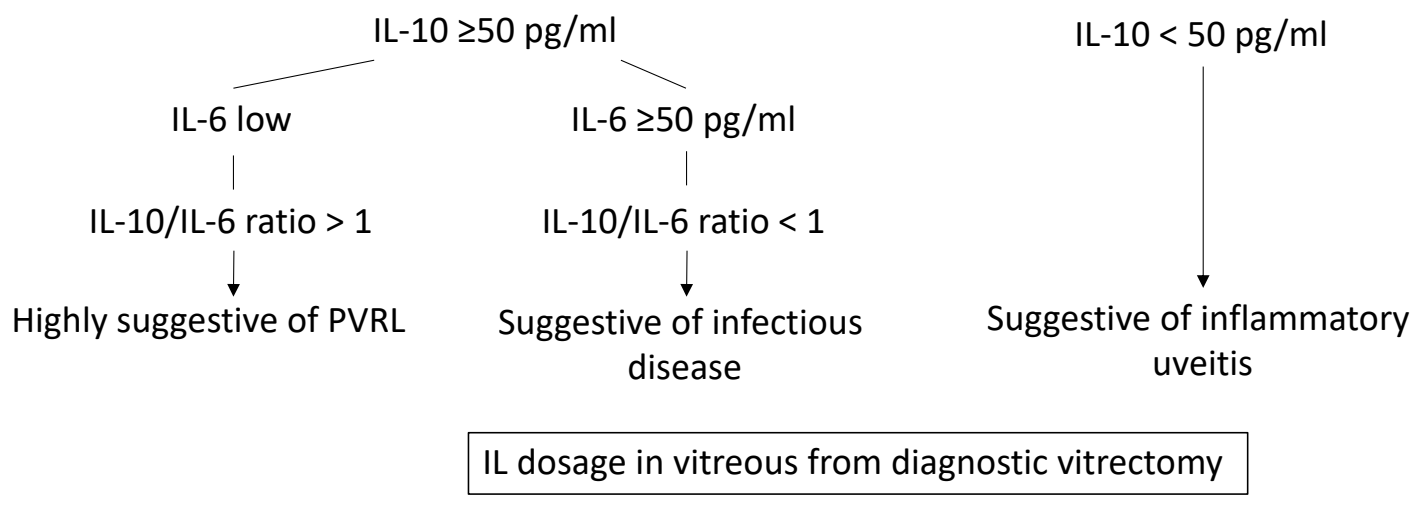

IL-10 $\geq 400 \mathrm{pg} / \mathrm{ml}$ and IL-10/IL-6 ratio $>1$

Highly suggestive of PVRL

B.

ISOLD score

ISOLD formula for aqueous: $-12.871+5.533 \times \log ($ IL-10 + 1) $-1.614 \times \log ($ IL- $6+1)$. ISOLD formula for vitreous: $-12.208+4.648 \times \log ($ IL-10 + 1) $-1.669 \times \log ($ IL-6 + 1).

Each ISOLD value is associated with a probability calculated using the following function:

Probability (intraocular lymphoma) $=1 /(1+\exp [-I S O L D])$ 


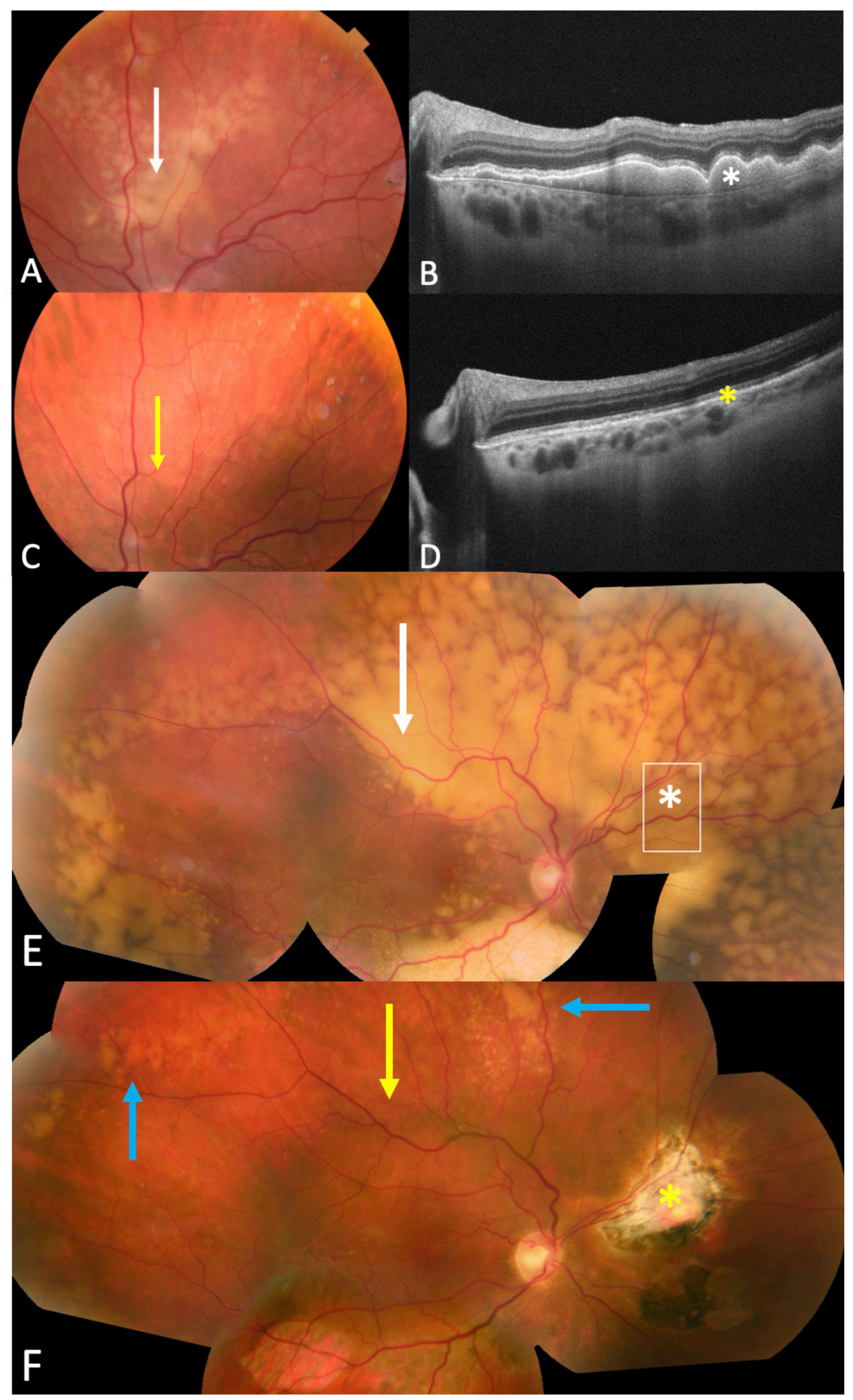

